\title{
Vegetation Response of a Dry Shrubland Community to Feral Goat Management on the Island of Moloka'i, Hawai'i
}

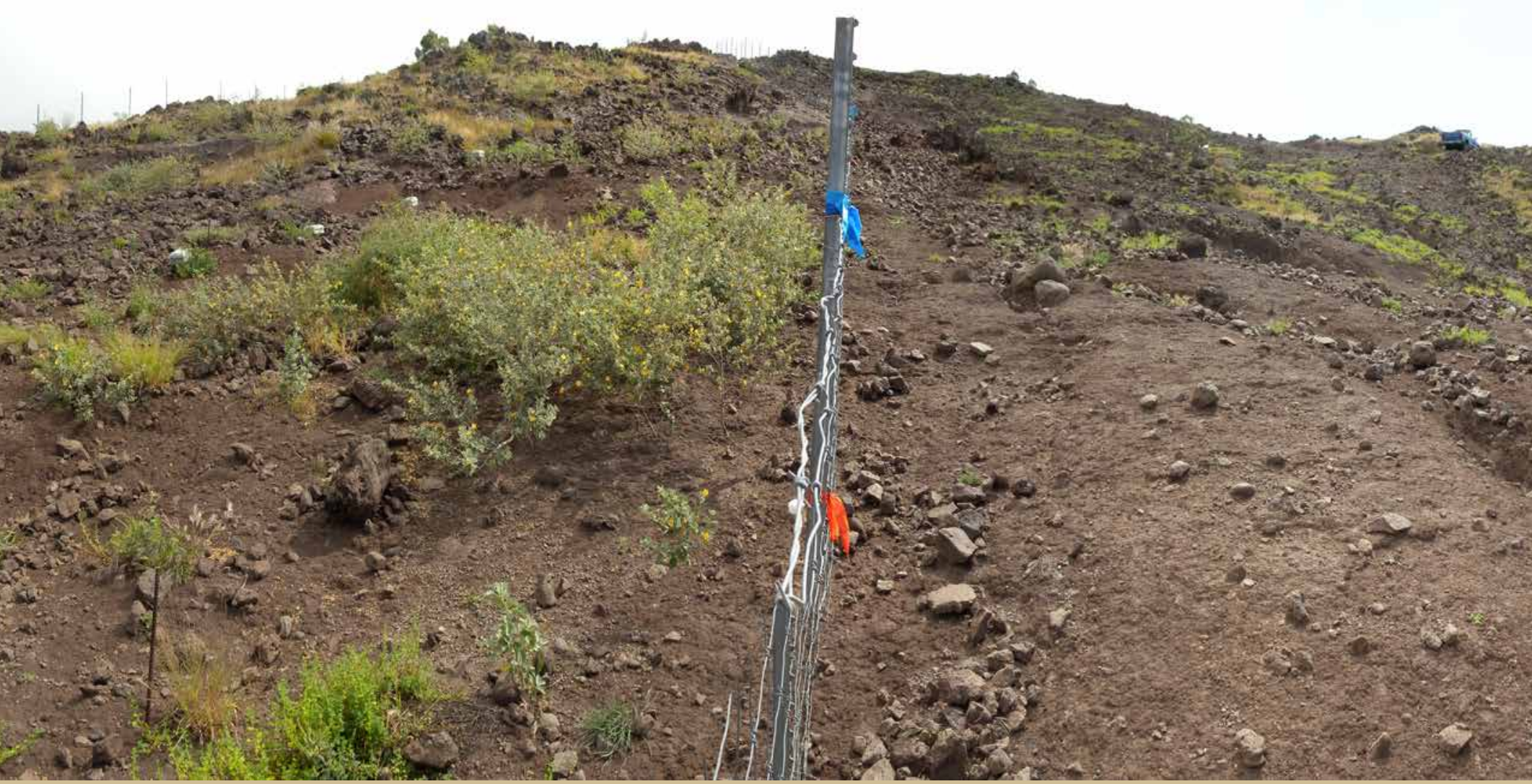

Scientific Investigations Report 2017-5136 
Cover. View of the U.S. Geological Survey Ridge-to-Reef study site on the island of Moloka'i, showing the difference in vegetation on the left side (fenced -goats excluded) versus the right side (unfenced). Photograph by James D. Jacobi, U.S. Geological Survey, 2010. 


\section{Vegetation Response of a Dry Shrubland Community to Feral Goat Management on the Island of Moloka'i, Hawai'i}

By James D. Jacobi and Jonathan Stock

Scientific Investigations Report 2017-5136 


\title{
U.S. Department of the Interior \\ RYAN K. ZINKE, Secretary
}

\section{U.S. Geological Survey \\ William H. Werkheiser, Deputy Director \\ exercising the authority of the Director}

\author{
U.S. Geological Survey, Reston, Virginia: 2017
}

For more information on the USGS-the Federal source for science about the Earth, its natural and living resources, natural hazards, and the environment-visit https://www.usgs.gov or call 1-888-ASK-USGS.

For an overview of USGS information products, including maps, imagery, and publications, visit https://store.usgs.gov.

Any use of trade, firm, or product names is for descriptive purposes only and does not imply endorsement by the U.S. Government.

Although this information product, for the most part, is in the public domain, it also may contain copyrighted materials as noted in the text. Permission to reproduce copyrighted items must be secured from the copyright owner.

Suggested citation:

Jacobi, J.D., and Stock, J., 2017, Vegetation response of a dry shrubland community to feral goat management on the island of Moloka'i, Hawaii'i: U.S. Geological Survey Scientific Investigations Report 2017-5136, 28 p., https://doi.org/10.3133/sir20175136.

ISSN 2328-0328 (online) 


\section{Acknowledgments}

We would like to thank the many people and organizations that have made this research possible. The overall design of the U.S. Geological Survey's Ridge-to-Reef (USGS-R2R) research program on Moloka'i was developed with the help and support of Ed Misaki, Russell Kallstrom, and Brian Naeole of The Nature Conservancy of Hawai'i (TNCH); the TNCH staff also constructed the fence with materials provided by Guy Hughes of the Kalaupapa National Historical Park (NPS). Permission to access and work in our study area was granted by the Kawela Plantation Homeowners' Association (KPHA), with constant support from Juanita Colon, the KPHA general manager. A special thanks to the many people who helped with collection of the vegetation data in the field including Christine Ogura, Gordon Tribble, Sara Rosa, Loyal Mehrhoff, Steve and Isaac Miller, Rick Palmer, Steve Hess, Lucas Fortini, Jonathan Price, Sam 'Ohu Gon III, Kevin Schmidt, and Maiana Hanshaw. Kevin Brinck provided very helpful advice on data analysis methods and interpretation of our results. Steve Hess and Greg Koob also provided constructive comments when they reviewed this manuscript.

Additionally, we thank Bob and Elizabeth Granger, long-time residents of Kawela Plantations, who have always supported this project with their great hospitality and humor. Finally, this effort would not have been accomplished without input and camaraderie from the other members of the USGS R2R Project: Pat Chavez, Mike Field, Maiana Hanshaw, Dave Helweg, Loyal Mehrhoff, Kevin Schmidt, Bill Steiner, John Stock, and Gordon Tribble.

Funding for this project was provided by the Western Region and National Office of the USGS under the Ecosystems and Invasive Species Programs, as well as from the USGS Pacific Island Ecosystems Research Center. Administrative support was provided by the Hawaili Cooperative Studies Unit and the USGS Pacific Island Ecosystems Research Center 


\section{Contents}

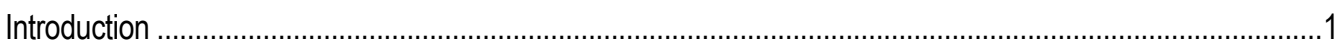

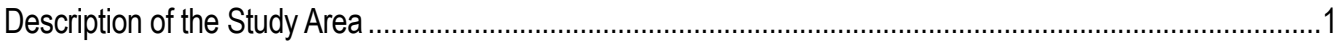

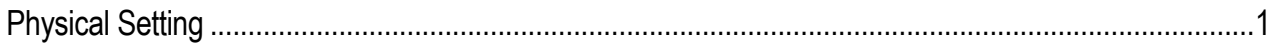

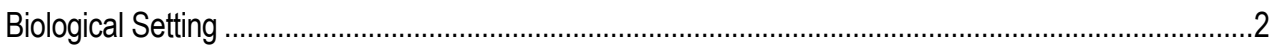

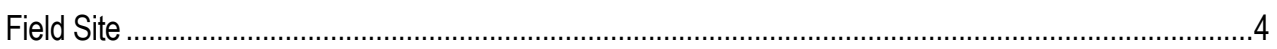

Ungulate Populations and Goat Control Efforts in the Study Area ...................................................

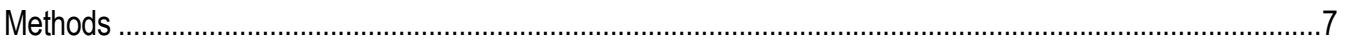

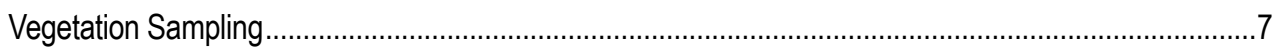

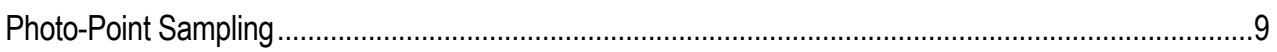

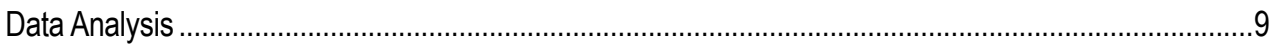

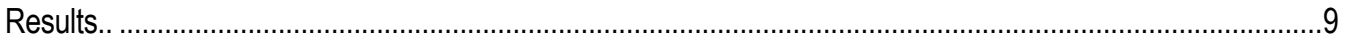

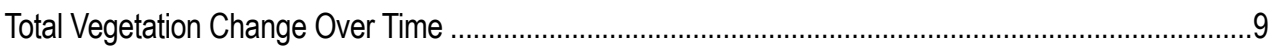

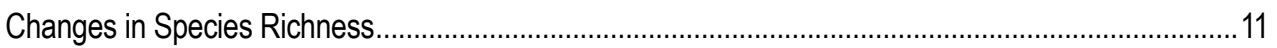

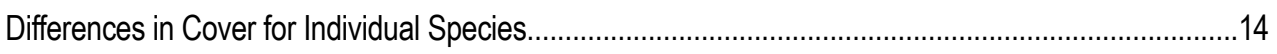

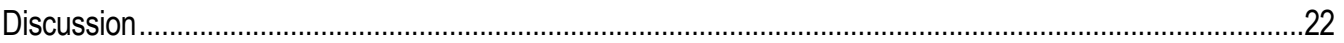

Vegetation Cover Change Relative to Goat Population Levels ......................................................22

Species Cover Change Relative to Goat Population Levels .............................................................22

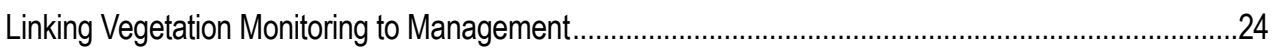

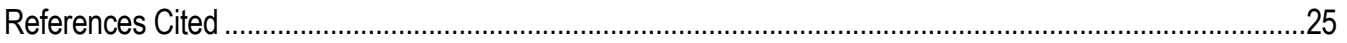

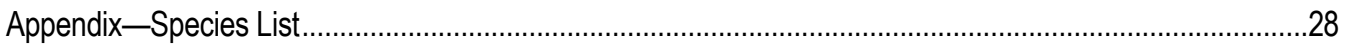

\section{Figures}

1. Overview map of the U.S. Geological Survey Ridge-to-Reef study area on the island of Moloka'i, Hawai'i

2. Map of moisture zones for the U.S. Geological Survey Ridge-to-Reef study area on the island of Moloka'i, Hawaíi.

3. Map of vegetation zones for the U.S. Geological Survey Ridge-to-Reef study area on the island of Moloka'i, Hawaiti...

4. Map of plant communities determined by Jacobi and Ambagis (2013) for the U.S. Geological Survey Ridge-to-Reef study area on the island of Moloka'i, Hawai'i.

5. Aerial image taken in December 2008 showing the landscape and approximate location of the two study plots established within the U.S. Geological Survey Ridge-to-Reef study area ...

6. Photograph showing very sparse grass/shrub plant community at the edge of the east fork of Kawela Gulch, Moloka'i, Hawai'i

7. Graph showing number of goats observed during aerial surveys conducted in 2009-12 ..............6

8. Map of the fenceline around plot $\mathrm{K} 2$ and transects used to sample the vegetation in plots $\mathrm{K} 1$ and K2 in the U.S. Geological Survey Ridge-to-Reef study area on the island of Moloka'i......

9. Graph of mean annual rainfall for the period $1978-2007$ at the U.S. Geological Survey Ridge-toReef monitoring site on the island of Moloka'i . 
10. Photo-point series taken on transect 6 in plot $\mathrm{K} 1$ outside the fence, and on transect 6 in plot $\mathrm{K} 2$ inside the fence..

11. Upslope views of the U.S. Geological Survey Ridge-to-Reef study site on the island of Moloka'i in 2009, 2011, and 2014...

12. Graph of total vegetation cover for plot $\mathrm{K} 1$ and $\mathrm{K} 2$ during the April sampling periods from 2009 to 2014

13. Graph of total vegetation cover for plot $\mathrm{K} 1$ and $\mathrm{K} 2$ during the December sampling periods in 2009 and 2012.

14. Graph showing the number of plant species recorded within plots $\mathrm{K} 1$ and $\mathrm{K} 2$ in the U.S. Geological Survey Ridge-to-Reef Moloka'i study area during the December sampling periods ....13

15. Graph showing the number of plant species recorded within plots K1 and K2 in the U.S. Geological Survey Ridge-to-Reef Moloka'i study area during the April sampling periods

16. Photograph showing the native shrub Chenopodium oahuense growing inside the fenced area in plot $\mathrm{K} 2$

17. Graph showing percent cover of Melinis repens for the April sampling periods within plots K1 and K2 in the U.S. Geological Survey Ridge-to-Reef Moloka'i study area

18. Graph showing percent cover of Tridax procumbens for the April sampling periods within plots K1 and K2 in the U.S. Geological Survey Ridge-to-Reef Moloka'i study area

19. Photograph showing the native annual grass Panicum fauriei var. fauriei growing in plot $K 2$ in the U.S. Geological Survey Ridge-to-Reef Moloka'i study area

20. Photograph showing the native shrub Sida fallax growing in plot K2 in the U.S. Geological Survey Ridge-to-Reef Moloka'i study area

21. Graph showing percent cover of Panicum fauriei var. fauriei for the April sampling periods within plots K1 and K2 in the U.S. Geological Survey Ridge-to-Reef Moloka'i study area

22. Graph showing percent cover of Sida fallax for the April sampling periods within plots K1 and K2 in the U.S. Geological Survey Ridge-to-Reef Moloka'i study area

23. Graph showing percent cover of Festuca myuros for the April sampling periods within plots K1 and K2 in the U.S. Geological Survey Ridge-to-Reef Moloka'i study area

24. Graph showing percent cover of Dysphania carinata for the April sampling periods within plots K1 and K2 in the U.S. Geological Survey Ridge-to-Reef Moloka'i study area.

25. Aerial view of the U.S. Geological Survey Ridge-to-Reef erosion study area in 2009 showing the two plots, K1 and K2, and the fence line constructed around plot K2.

26. Aerial view of the U.S. Geological Survey Ridge-to-Reef erosion study area in 2015 showing the two plots, K1 and K2, and the fence line constructed around plot K2

\section{Tables}

1. Number of points sampled and total cover for vegetation of any species and bare ground in plots $\mathrm{K} 1$ and $\mathrm{K} 2$ during the April and December sampling periods.......

2. Percent cover for species recorded in plots $\mathrm{K} 1$ and $\mathrm{K} 2$ during the December sampling periods ......... 14

3. Percent cover for species recorded only in plot K1 or K2 during the April sampling periods................15

4. Percent cover for species recorded in both plot $\mathrm{K} 1$ and $\mathrm{K} 2$ during the April sampling periods..............15

5. Percent cover for all species recorded in plots $\mathrm{K} 1$ and $\mathrm{K} 2$ for the April sampling periods ....................16

6. Percent cover for all species recorded in plots $\mathrm{K} 1$ and $\mathrm{K} 2$ for the December sampling periods ...........17

7. Summary of the results from binary logistic regression analysis for plant species that could be analyzed and modeled.. 


\section{Conversion Factors}

International system of units to U.S. customary units

\begin{tabular}{|c|c|c|}
\hline Multiply & By & To obtain \\
\hline \multicolumn{3}{|c|}{ Length } \\
\hline millimeter (mm) & 0.03937 & inch (in.) \\
\hline centimeter (mm) & 0.3937 & inch (in.) \\
\hline meter $(\mathrm{m})$ & 3.281 & foot $(\mathrm{ft})$ \\
\hline \multicolumn{3}{|c|}{ Area } \\
\hline hectare (ha) & 2.471 & acre \\
\hline
\end{tabular}

\section{Datum}

Horizontal and vertical coordinate information is referenced to the North American Datum of 1983 (NAD 83); Spheroid: GRS_1980. Elevation, as used in this report, refers to distance above the vertical datum.

\section{Abbreviations}

$\begin{array}{ll}\text { BLR } & \text { binary logistic regression } \\ \text { EMoWP } & \text { East Moloka'i Watershed Partnership } \\ \text { KPHA } & \text { Kawela Plantation Homeowners' Association } \\ \text { NAD 83 } & \text { North American Datum of 1983 } \\ \text { USGS } & \text { U.S. Geological Survey } \\ \text { USGS-R2R } & \text { U.S. Geological Survey Ridge-to-Reef project area } \\ \text { UTM } & \text { Universal Transverse Mercator }\end{array}$




\title{
Vegetation Response of a Dry Shrubland Community to Feral Goat Management on the Island of Moloka'i, Hawai'i
}

\author{
By James D. Jacobi and Jonathan Stock
}

\section{Introduction}

The Hawaiian Islands are well known for their unique ecosystem assemblages that have a high proportion of endemic flora and fauna (Carlquist, 1980; Wagner and Funk, 1995; Ziegler, 2002). However, since human colonization of this archipelagostarting with the arrival of Polynesian sailors approximately 1,200 years ago (Kirch and Hunt, 1997; Kirch, 2007, 2011), and particularly following western contact in 1778 - thousands of non-native species have been introduced to the Islands and many of these alien species have had severe impacts on the native ecosystems (Smith, 1985; Stone and Scott, 1985; Staples and Cowie, 2001). Particularly damaging to these ecosystems are large mammals, including goats (Capra hircus), pigs (Sus scrofa), cattle (Bos taurus), deer (Axis axis and Odocoileus hemionus), and sheep (Ovis spp.), which are collectively referred to here as ungulates; they cause extensive damage to the native vegetation by their browsing, grazing, and trampling (Warshauer, 1998; Hess and others, 1999; Chynoweth and others, 2013). Similar impacts have been documented elsewhere, including New Zealand (Allen and others, 1984) and many other island ecosystems (Coblentz, 1978; Brockie and others, 1988; Loope and others, 1988).

Previous studies in Hawai'i have utilized fenced exclosures to assess the impacts of feral or wild ungulates on vegetation and the recovery potential for the native plant communities by comparing plant community composition, structure, and cover inside the fenced area (without ungulates) over time to the vegetation condition outside of the protection of the fence (Loope and Scowcroft, 1985; Cole and Litton, 2014; Leopold and Hess, 2017). In some cases, the native vegetation recovered once the animals were removed (Jacobi, 1981; Scowcroft and Giffin, 1983; Hughes and others, 2014). However, in other situations alien plants were more competitive and dominated the revegetation process after the impacts of ungulates had been reduced or eliminated (Loope and Scowcroft, 1985; Cabin and others, 2000).

This report describes the response of a highly degraded lowland dry habitat plant community located on the south slope of east Moloka' $i$, Hawai $i$, to reduction of browsing and grazing impacts caused by feral goats. For this study, vegetation response inside a fenced exclosure was compared to vegetation change in the area outside of the fence that was still accessible to goats. This study is part of the larger U.S. Geological Survey Ridge-to-Reef (USGS-R2R) research project conducted between 2008 and 2014 to better understand the magnitude of, and factors responsible for, increased erosion on Moloka' $i$. The upslope erosion has resulted in heavy sedimentation of the near-shore coral reef ecosystem on the leeward side of the island (Field and others, 2008; Stock and others, 2011; Jacobi and Ambagis, 2013). The project area and adjacent lands are managed by the East Moloka' $i$ Watershed Partnership (EMoWP) to restore the vegetation and reduce erosion on the leeward side of the island (Hawai' $i$ Association of Watershed Partnerships, 2014).

Specific questions addressed in this vegetation change study include:

1. How does the vegetation composition, structure, and cover respond to different population levels of feral goats in this area?

2. Are there plant species that can be used as indicators of different population levels of goats?

3. Can native plants recover and become dominant again with the reduction or elimination of goats from this area?

4. Are there invasive plant species that respond favorably to reduction of goat populations and could result in additional management threats to this area over time?

5. How does the succession of vegetation following goat control relate to the original composition and structure of the plant communities that were formerly found in this area?

\section{Description of the Study Area}

\section{Physical Setting}

The USGS-R2R study area is located on the south-facing slope of the eastern side of the island of Moloka' $i$, fifth largest of the main Hawaiian Islands (Juvik and others, 1998). This area encompasses approximately 5,000 hectares extending from Kawela Gulch on the west to Kamalō Gulch on the east, and from sea level to 1,365 meters in elevation at the highest point on the ridge above Pelekunu Valley to the north (fig. 1). The study area includes several Hawaiian land divisions (ahupua'a) including Kawela, Kamalō, Mākolelau, Kapuaoko‘olau, and Keonekū'ino. These watersheds are carved into basaltic lavas erupted between 1.75 and 1.31 million years ago, and include cinder and spatter cones at upper elevations (Sherrod and others, 2007). 


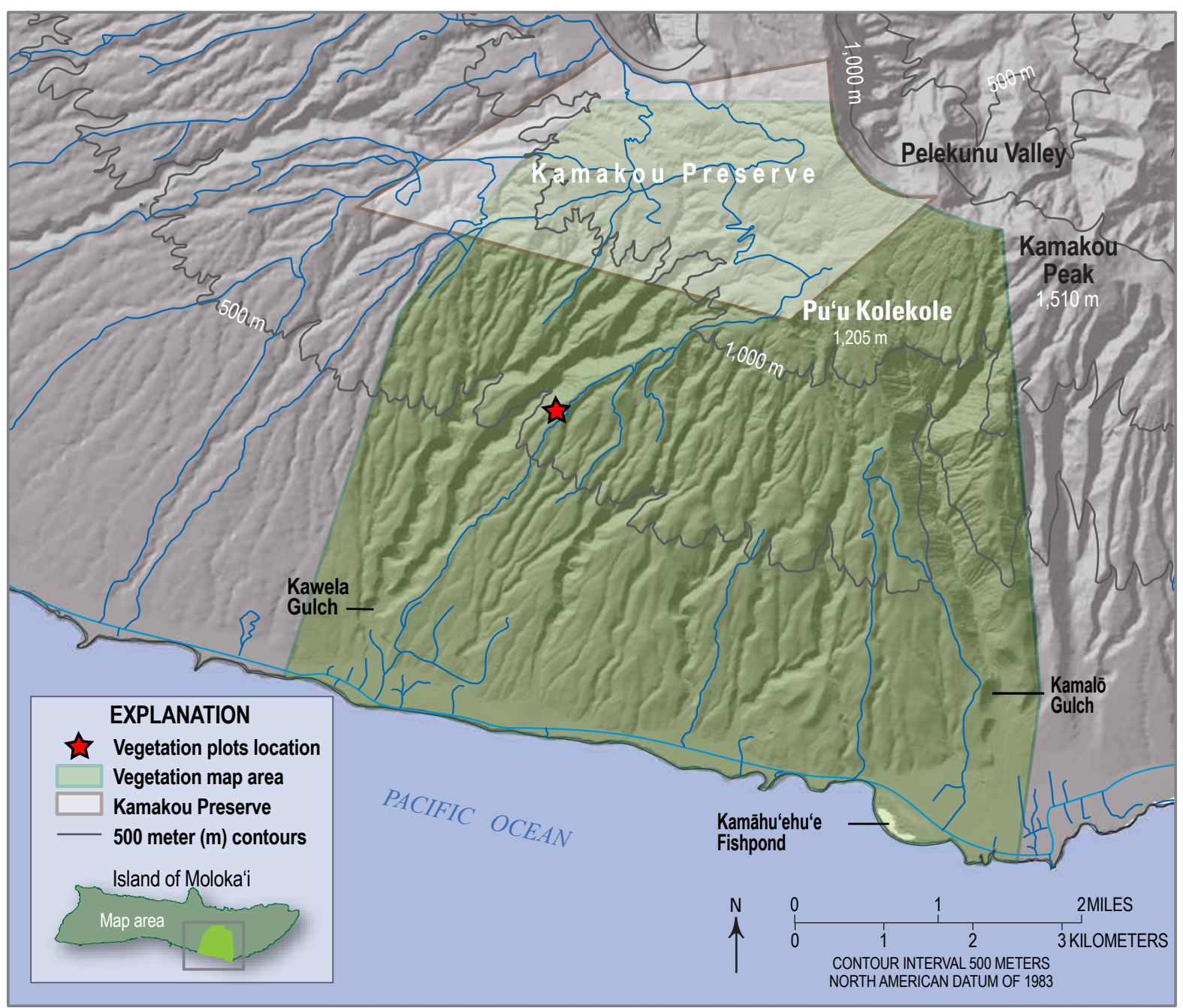

Figure 1. Overview map of the U.S. Geological Survey Ridge-to-Reef (R2R) study area on the island of Moloka'i, Hawai'i.

The research site is located on the leeward side of the island, protected from the prevailing northeast trade winds, which persist for more than 75 percent of the year (Giambelluca and others, 2012). The lower two-thirds of the study area is a relatively dry habitat, while the upper third is either mesic (moist) or wet native forest or shrubland. Annual rainfall ranges from 305 millimeters at the coast to as much as 3,400 millimeters at the Pelekunu Valley ridgeline (Giambelluca and others, 2012). This side of the island of Moloka $i$ is driest during the summer months, with less than 5 millimeters of rainfall per month falling at the coast from June to September (Giambelluca and others, 2012). Price and others (2012) mapped seven moisture zones on this slope with the driest habitats (arid and very dry) at lower elevations and wet habitats (moderately wet and very wet) at the upper elevations of the study area (fig. 2).

Soils are poorly developed in the lower elevation dry habitat zone, occurring as patches between rocky outcrops. This patchiness may be original, but it may also reflect increased erosion owing to reduced vegetation cover after decades of wildfire and extensive grazing by cattle and goats in this area. Most of the soils here were mapped as "very stony land" or "rough mountainous land" by the Natural Resources Conservation Service. A few organic soils were mapped in wet areas above 1,000 meters in elevation, and at the coast as clay-loam soils (U.S. Department of Agruculture, 2012).

\section{Biological Setting}

Price and others (2012) identified five vegetation zones on the leeward side of east Moloka'i (fig. 3), which provide a framework for describing the various plant communities that are currently, or were previously, found there. A recent map by Jacobi and Ambagis (2013) describes the current distribution of the vegetation throughout the larger USGS-R2R study area (fig. 4). In the upper elevation wet and mesic habitats, the vegetation is dominated by the native tree 'ōhi'a (Metrosideros polymorpha) with a mixed native fern and shrub understory. Below this forest zone is a mesic native shrubland that contains elements of the upper wet forest, as well as plant species from the original dry shrub/grass communities that formerly prevailed downslope. The natural vegetation in the dry, lower 

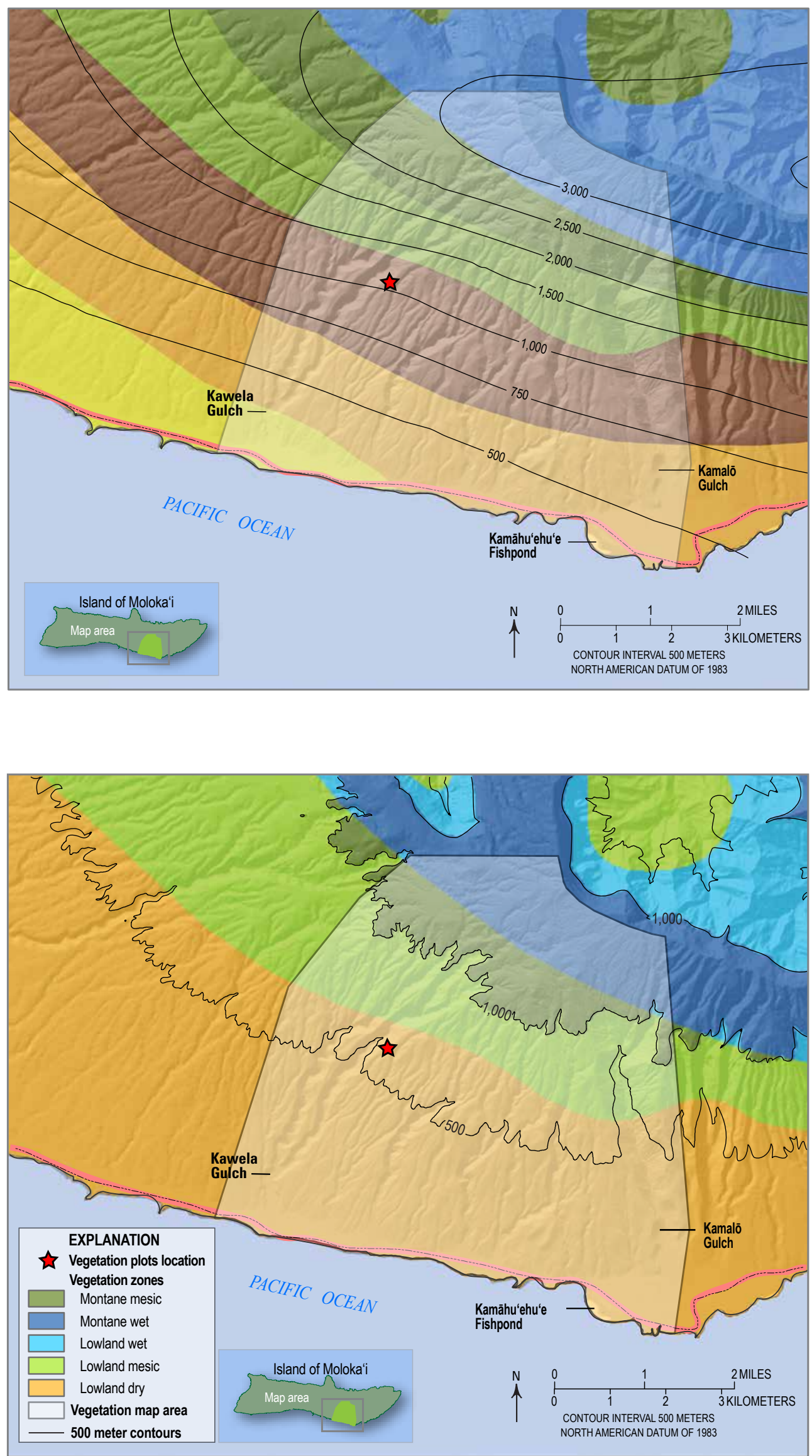

Figure 2. Map of moisture zones for the U.S. Geological Survey Ridge-to-Reef (R2R) study area on the island of Moloka'i, Hawai'i. Data from Price and others (2012).

\begin{tabular}{|l|l|}
\hline EXPLANATION \\
Vegetation plots location \\
Moisture zones and rainfall \\
Very wet \\
Moderately wet \\
Moist mesic \\
Seasonal mesic \\
Moderately dry \\
Very dry \\
Arid \\
Vegetation map area \\
\hline- Major roads \\
Annual rainfall, \\
in millimeters
\end{tabular}

Figure 3. Map of vegetation zones for the U.S. Geological Survey Ridge-to-Reef (R2R) study area on the island of Moloka'i, Hawai'i. Data from Price and others (2012). 


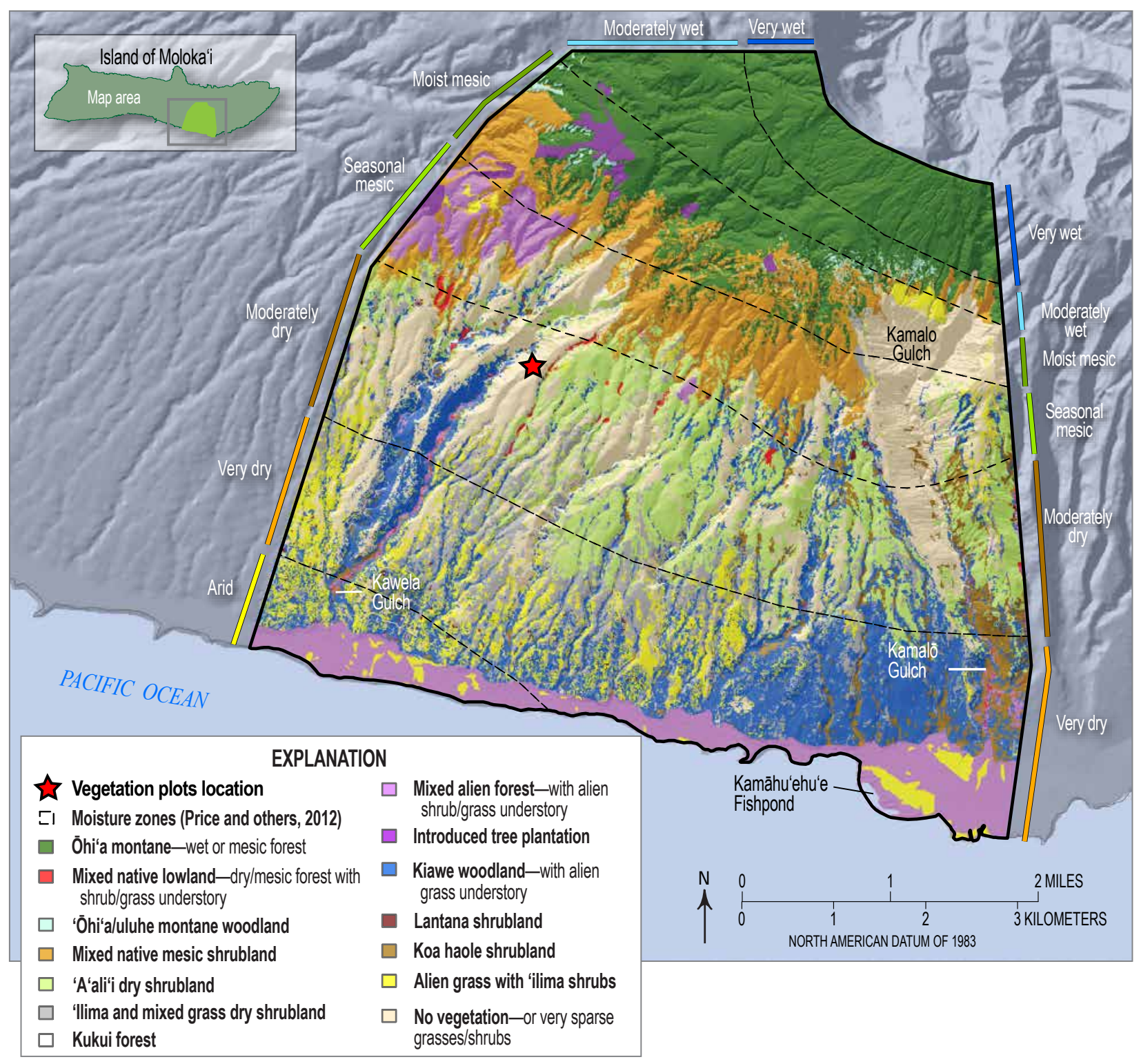

Figure 4. Map of plant communities determined by Jacobi and Ambagis (2013) for the U.S. Geological Survey Ridge-to-Reef study area on the island of Moloka'i, Hawai'i.

two-thirds of the study area has been dramatically altered by nearly two centuries of impacts from introduced ungulates, invasive plant species, cattle ranching, widespread logging of sandalwood ('iliahi) trees (Santalum spp.), and wildfire (Jacobi and Ambagis, 2013). These same factors have been responsible for degrading similar habitats throughout the Hawaiian Islands since human colonization (Cuddihy and Stone, 1990; Pratt and Jacobi, 2009). Jacobi and Ambagis (2013) speculated that the lowland mesic and dry habitats in the study area were previously covered with a highly diverse mix of native forest, woodland, and shrub communities. However, only remnants of these original vegetation types remain today, mainly as isolated pockets of forest or shrub stands in areas that are protected from feral ungulates.

\section{Field Site}

We assessed the potential for vegetation recovery following goat control in two study plots (K1 and K2) located in a highly degraded and eroded site at 670 meters in elevation, just east of Kawela Gulch (715,380 meters E, 2,333,900 meters N, UTM Zone 4, NAD 83 datum). We selected this site because it was representative of eroding barren areas that contribute fine sediment to the near-shore reef ecosystem during heavy rainfalls, and because it was accessible by a nearby dirt road. When the site was visited in December 2008 most of the ground was bare, with just a few scattered individuals of native and alien grasses and shrubs (fig. 5). Much of the vegetation had been removed by 


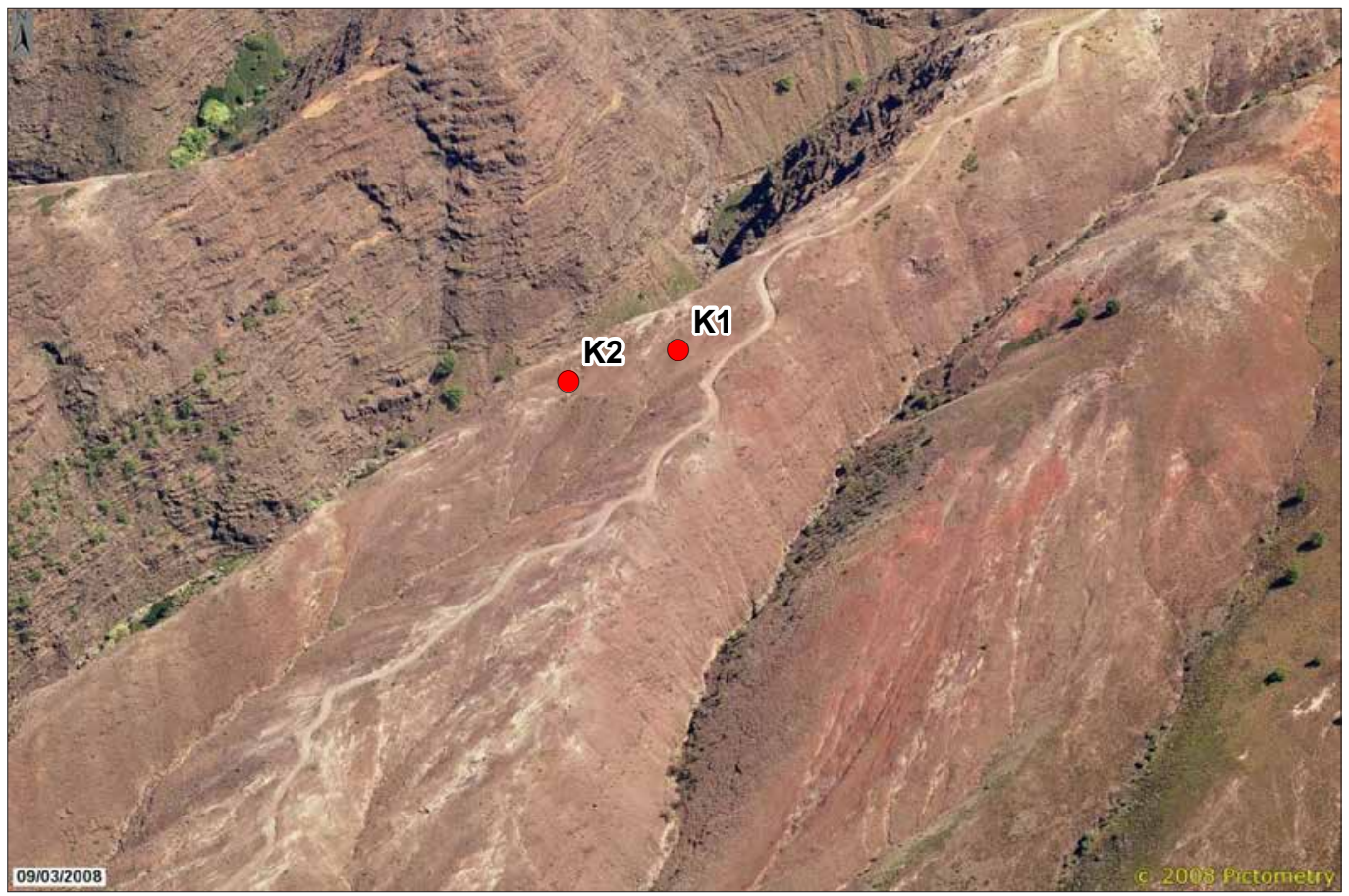

Figure 5. Aerial image taken in December 2008 showing the landscape and approximate location of the two study plots (K1 and K2) established within the U.S. Geological Survey Ridge-to-Reef study area. Image copyright by Pictometry International.

browsing and grazing from feral goats, which were frequently observed there during the daytime. In addition to live sightings, goat presence was documented by an abundance of browse signs seen on the remaining shrubs and grasses, and by the presence of fresh goat droppings throughout the area. Only fragmented plant communities and scattered individual plants were seen there in December 2008 (fig. 6). The most abundant (but with very low cover) plant species seen there at that time were the native shrub 'ilima (Sida fallax), and two alien annual grass species: Bromus rubens, and Festuca myuros. A detailed list of plant species recorded in this area throughout the project is provided in the appendix. The vegetation unit mapped at this site by Jacobi and Ambagis (2013) was "No vegetation or very sparse grasses/shrubs."

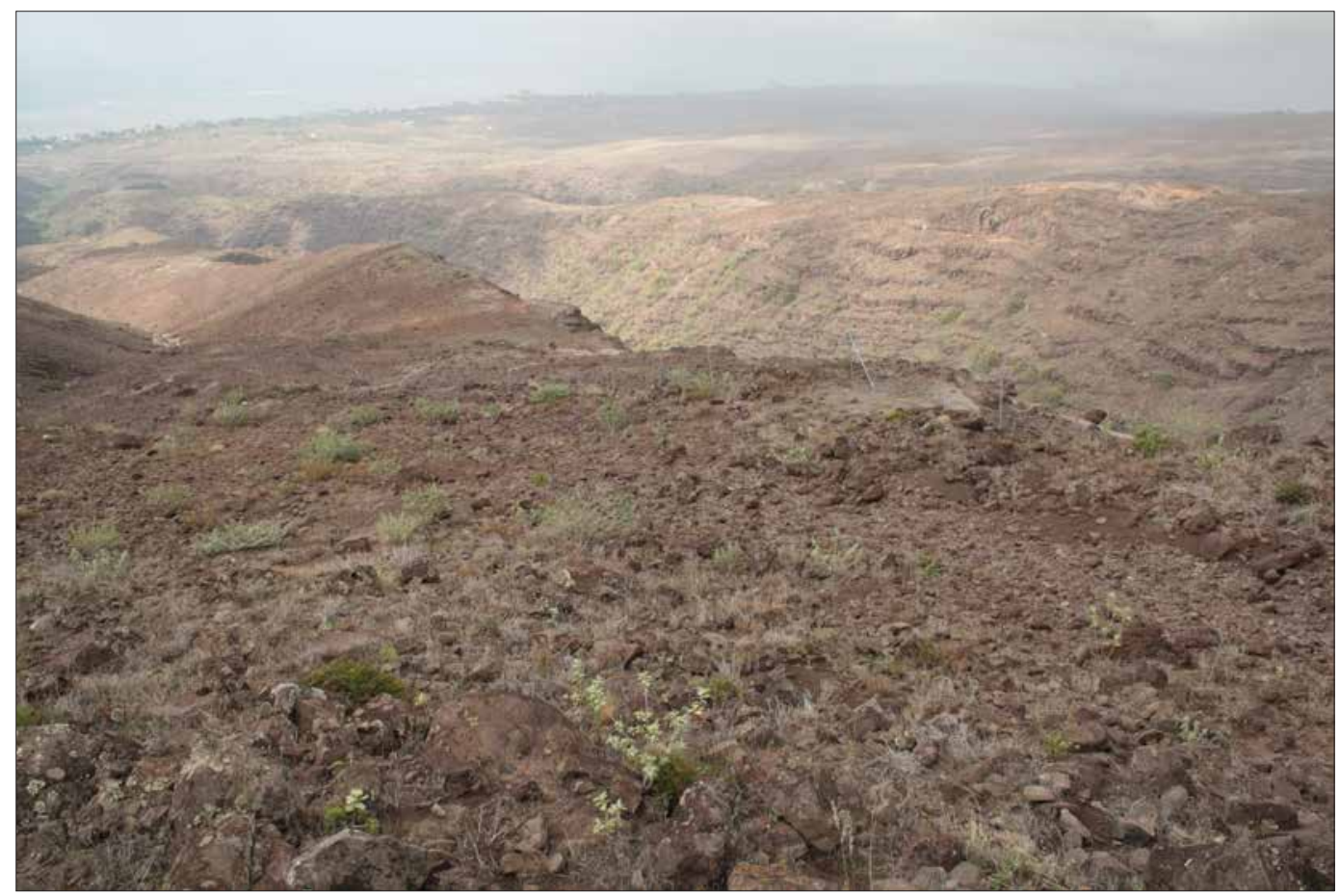

Figure 6. Photograph showing very sparse grass/ shrub plant community at the edge of the east fork of Kawela Gulch, Moloka'i, Hawaili; viewed from plot K1, looking toward plot K2. Photograph taken in December 2009. 


\section{Ungulate Populations and Goat Control Efforts in the Study Area}

All terrestrial mammals except the Hawaiian hoary bat (Lasiurus cinereus semotus) have been brought to the Hawaiian Islands by humans (Tomich, 1986; Staples and Cowie, 2001; Ziegler, 2002). Early Polynesian settlers in Hawai'i introduced domesticated pigs, which are thought to have been most abundant around human settlements (Tomich, 1986; Staples and Cowie, 2001). Domestic pigs and goats were introduced by Captain James Cook in 1778, sheep in 1791, and cattle arrived with Captain George Vancouver in 1793 (Tomich, 1986). All of these species have been brought into Hawai'i numerous times since then (Tomich, 1986; Maly and Wilcox, 2000), and many of these ungulate species are now widely distributed on most of the main Hawaiian Islands. Feral goats were well established on the island of Moloka' $i$ by the early 1800 s and commercial cattle ranching was initiated there in 1853 (Carlson, 1952). Axis deer were brought to Hawai' $i$ in 1867 as a gift from the Hawaiian Consul in Hong Kong to King Kamehameha V. Seven deer were released initially on the island of Moloka' $i$, then more were subsequently introduced on the island of Lāna' $i$, and then to Maui in 1959 (Cooke, 1949; Tomich, 1986). Axis deer now range up into the rainforest habitats on Moloka' $i$, but are most abundant in the coastal, dry habitats around this island.

Much of the land that falls within the lower two-thirds of the study area was actively managed as a cattle ranch through the mid1900s (Kawela Plantation Homeowners' Association, 2014). As cattle ranching ended, it is likely that goat populations increased. The area has also been used by the public for subsistence and sport hunting, but these activities declined after the coastal lands were developed into a residential subdivision by Kawela Plantations in the late 1970s (Kawela Plantation Homeowners' Association,
2014). In recent years, many of the landowners across most of the eastern portion of the island of Moloka' $i$, including Kawela Plantation Homeowners Association (KPHA), joined the East Moloka'i Watershed Partnership (EMoWP). This partnership has focused on active control of invasive plant and animal species, as well as greater wildfire prevention efforts, to stimulate recovery of the native plant communities, enhance rainfall infiltration into the aquifer, and reduce surface erosion and related impacts of sediment on the near-shore coral reef ecosystem (Hawai' $i$ Association of Watershed Partnerships, 2014).

In 2008, the EMoWP finished constructing an ungulateproof fence line across the upper part of the Kawela watershed on an elevation contour that runs along the lower extent of the native mesic shrubland and portions of the wet/mesic 'ōhi'a forest. Despite some continued sport hunting in recent years, goats remained abundant throughout the area below the fence line, including the R2R plot area. Hawai' $i$ Division of Forestry and Wildlife and EMoWP staff began hunting goats, both from the ground and the air, in 2009 (E. Misaki, The Nature Conservancy of Hawai' $i$, oral commun., 2008). To monitor the effectiveness of this control effort, the EMoWP also conducted annual airborne counts of goats and other animals. With the initiation of more intense hunting in June 2009, and particularly with increased use of aerial shooting, goat populations were reduced from more than 800 animals observed in 2009 to approximately 200 animals observed at the end of 2012 (fig. 7). Aerial counts of goats were not conducted in this area after September 2012, since all the animals seen each time from the air, or on subsequent ground hunts, were shot and killed. Even with intensified hunting, goats were still occasionally seen across most of the study area through 2014 as there were no significant barriers (in other words, fences or inaccessible topography) to prevent their ingress from adjacent lands outside the animal control zone (E. Misaki, The Nature Conservancy of Hawai' $i$, oral commun, 2014).
Figure 7. Graph showing number of goats observed during aerial surveys conducted in 2009-12. Data provided by E. Misaki, The Nature Conservancy of Hawai'i, oral commun., 2014.

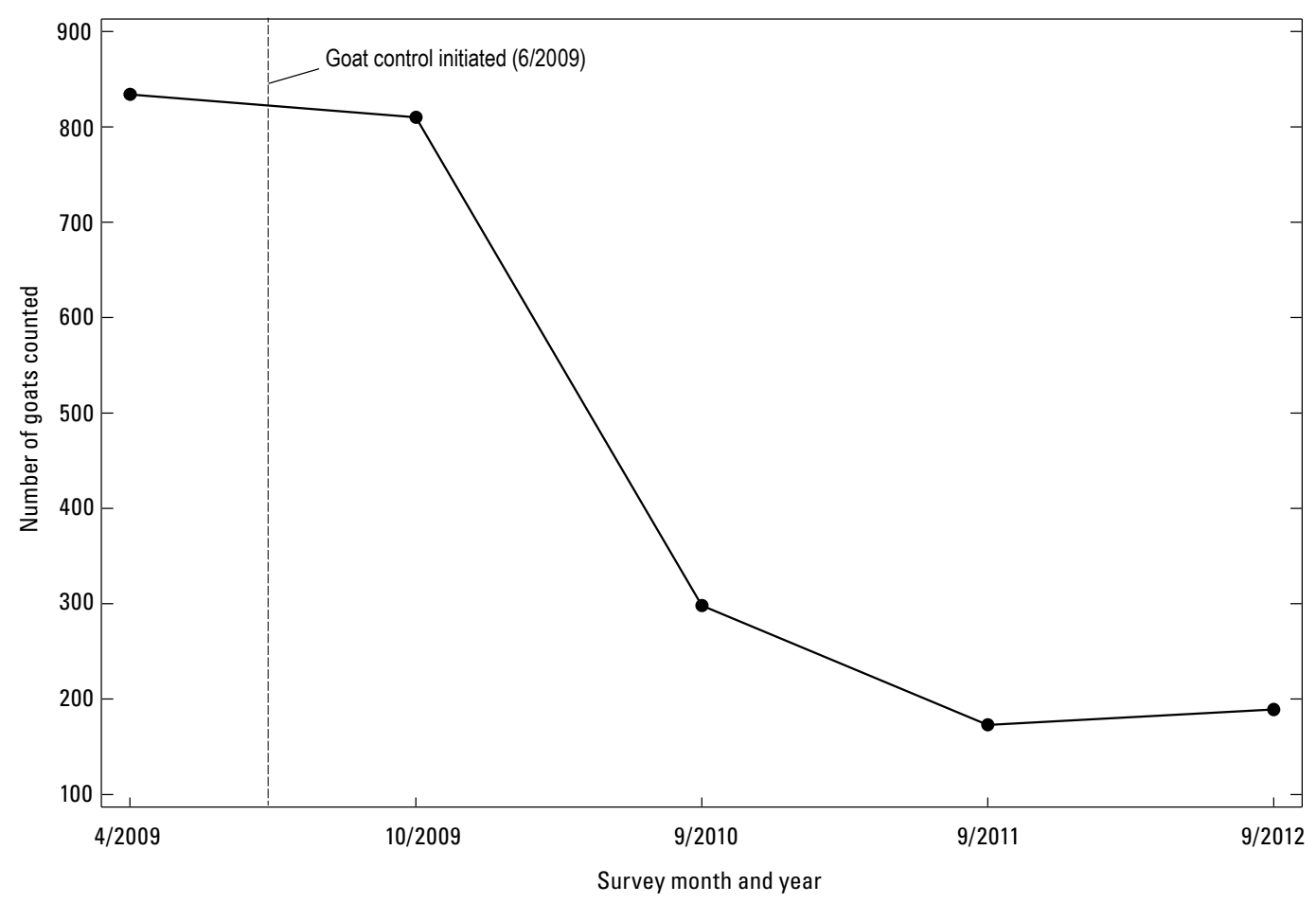




\section{Methods}

This study was designed to assess the response of vegetation in two adjacent research plots after animal control measures were conducted across the landscape. Although the focus of this report is evaluating vegetation change in these two plots over time, concurrent studies were conducted in these sites to determine the relation between vegetation cover and the genesis, transport, and delivery of fine sediments from this site downslope to the larger Kawela Gulch drainage and into the near-shore coral reef (Stock and others, 2011).

Two study plots (K1 and K2) were established in small adjacent watershed-catchment cells mantled by thick soils formed from volcanic air-fall (fig. 5). Both plots were initially found to be mostly barren rocky ground with very little plant cover. Each plot is roughly 0.25 hectares in size, and located at approximately 670 meters in elevation above sea level (U.S. Geological Survey, 2014). One site (plot K2) was arbitrarily selected to be enclosed by an ungulate-proof fence while the other one (plot K1) had unrestricted access for goats. The fence was constructed around the K2 plot in December 2008.

\section{Vegetation Sampling}

We conducted vegetation monitoring using standard methods described by Elzinga and others (2001) and MuellerDombois and Ellenberg (2002). Sampling points were located every 20 centimeters along transects that ran nearly parallel to the elevation contours in each plot (fig. 8). To establish the transects, a meter tape was stretched from the upslope to downslope ends of the fenced $\mathrm{K} 2$ exclosure (total distance of 95 meters). This tape served as a baseline for locating multiple transects running along contour lines across the catchment. We chose a random number, between 1 and 95, to determine the starting point for the first transect across the baseline. From that point, nine transects were systematically established at 10 meter intervals both above and below the initial starting point to the top and bottom extents of the fence, and following

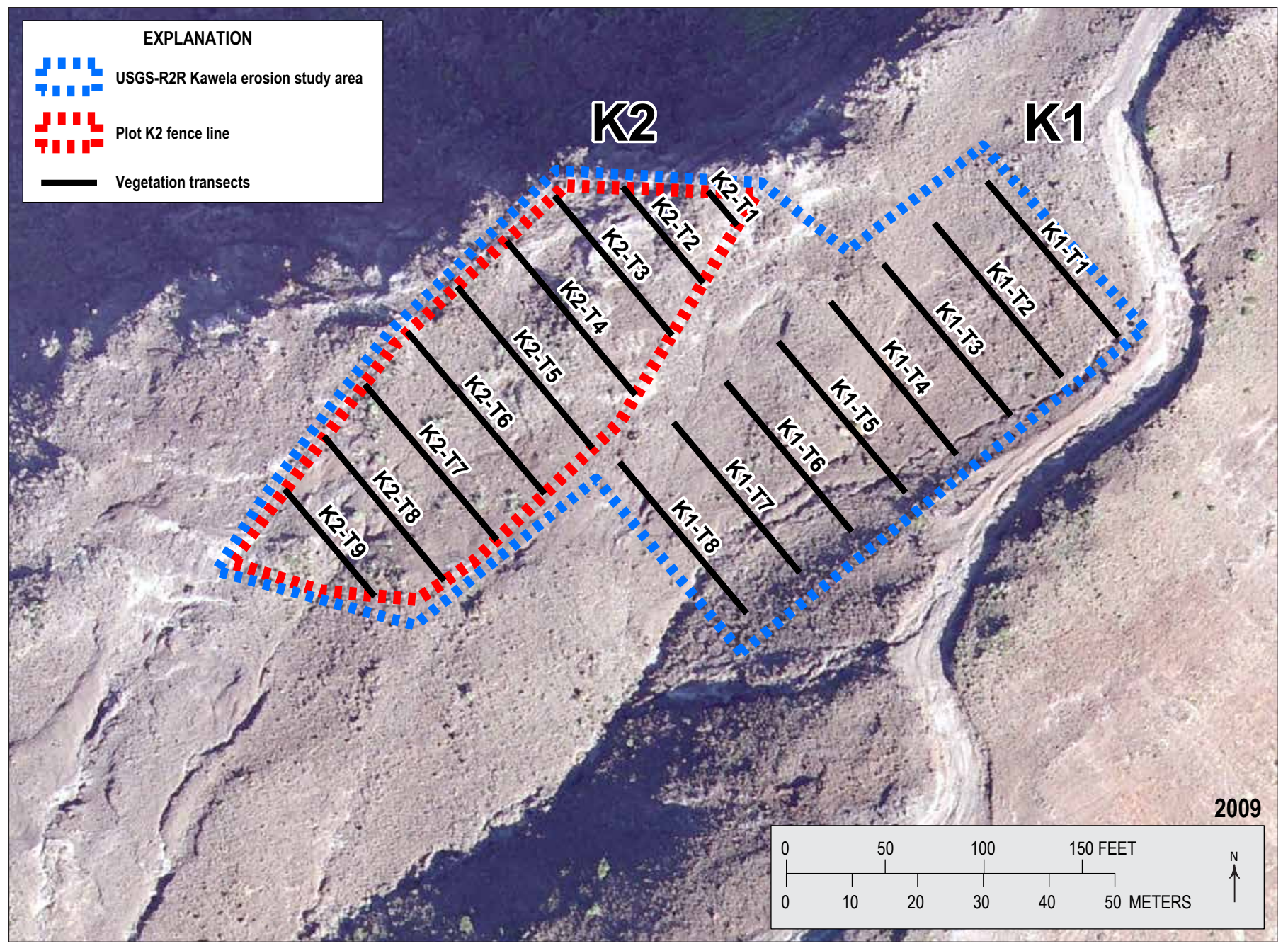

Figure 8. Map of the fenceline around plot K2 and transects used to sample the vegetation in plots K1 and K2 in the U.S. Geological Survey Ridgeto-Reef (R2R) study area on the island of Moloka'i. Image copyright 2009 by Pictometry International. 
a compass bearing of $140^{\circ}$ true north $\left(129^{\circ}\right.$ magnetic north $)$ across the exclosure. Transect length in plot K2 varies with fence-to-fence width. In this plot, each transect ran from the west side of the fence to the east side and ranged in length from less than 8 meters (transect 1) to 35 meters (transect 6). We used the same process to establish eight transects in K1, with all transects of equal length (30 meters) in the absence of a fence boundary. Transect 1 in the fenced K2 plot was just 7.6 meters long and mostly ran across bare rock with little chance for plant recovery within the short time span of this study; therefore, data from this transect was not included in the current analysis. All other transects in both plots ran through substrates that ranged from fine sand or silt to broken rock stones and boulders.

We recorded plant species frequency using the poleintercept sampling method, which is a variation of the point-intercept technique described by Mueller-Dombois and Ellenberg (2002). The frequency values for each species provide an estimate of cover for the sampled area (Elzinga and others, 2001). We stretched a meter tape from the start to end points on each transect. Next, we placed an aluminum pole, approximately 0.5 centimeter in diameter and 2 meters tall, vertically at 20 centimeter intervals along the transect tape, starting at 10 centimeters. A data point was recorded for any plant part that touched the pole at that spot. Dead plant material that touched the pole was only recorded as a species if it was connected to a living plant. Multiple species could be recorded at any sampling point, but a species was only recorded once even if it touched the pole multiple times at that point. We recorded the value "BARE" if no plant species touched the pole at a sample point. Comments were also recorded on the datasheet to describe goat sign (for example, browsing evidence or droppings), or to make note of any additional plant species adjacent to the transect that were not recorded at the sampling points.

For each sampling period, we collected between 1,120 and 1,200 pole-intercept points within each of the plots (table 1). Slight differences in the number of sample points per date within the $\mathrm{K} 2$ plot (inside the fence) were caused by slightly different tension on the tape when it was stretched from the west to the east fence on each transect. Additionally, at a few points in both plots we recorded "NO DATA" when the placement of the sampling pole at a specified spot along the transect fell on top of some of the erosion monitoring instruments or related infrastructure; the data from these sampling points were not included in the analysis.

We sampled the vegetation in both plots (K1 and K2) annually from April 2009 through April 2014, supplemented by collections in early December 2009 and December 2012. The April sampling time captures an expected vegetation density peak at the end of the wet season, and the early December sampling captures these plant communities at the end of the dry summer when plant species presence and cover might be minimized (fig. 9). In addition to pole-intercept

Table 1. Number of points sampled and total cover for vegetation of any species and bare ground in plots K1 and K2 during the April and December sampling periods.

\begin{tabular}{|c|c|c|c|c|}
\hline Date & Site & Points sampled & Vegetated (in percent) & Bare (in percent) \\
\hline \multirow[t]{2}{*}{ April 2009} & K1 - Unfenced & 1,199 & 22.9 & 77.1 \\
\hline & K2 - Fenced & 1,130 & 27.6 & 72.4 \\
\hline \multirow[t]{2}{*}{ April 2010} & $\mathrm{~K} 1$ - Unfenced & 1,195 & 19.2 & 80.8 \\
\hline & K2 - Fenced & 1,130 & 24.9 & 75.1 \\
\hline \multirow[t]{2}{*}{ April 2011} & K1 - Unfenced & 1,196 & 53.6 & 46.4 \\
\hline & K2 - Fenced & 1,124 & 51.1 & 48.9 \\
\hline \multirow[t]{2}{*}{ April 2012} & K1 - Unfenced & 1,194 & 36.7 & 63.3 \\
\hline & K2 - Fenced & 1,131 & 26.1 & 73.9 \\
\hline \multirow[t]{2}{*}{ April 2013} & K1 - Unfenced & 1,192 & 71.1 & 28.9 \\
\hline & K2 - Fenced & 1,129 & 57.0 & 43.0 \\
\hline \multirow[t]{2}{*}{ April 2014} & K1 - Unfenced & 1,195 & 76.8 & 23.2 \\
\hline & K2 - Fenced & 1,130 & 54.5 & 45.5 \\
\hline \multirow[t]{2}{*}{ December 2008} & K1 - Not sampled & & & \\
\hline & K2 - Fenced & 1,142 & 0.7 & 99.3 \\
\hline \multirow[t]{2}{*}{ December 2009} & K1 - Unfenced & 1,198 & 0.9 & 99.1 \\
\hline & K2 - Fenced & 1,120 & 4.9 & 95.1 \\
\hline \multirow[t]{2}{*}{ December 2012} & $\mathrm{~K} 1$ - Unfenced & 1,200 & 15.8 & 84.2 \\
\hline & K2 - Fenced & 1,131 & 13.5 & 86.5 \\
\hline
\end{tabular}




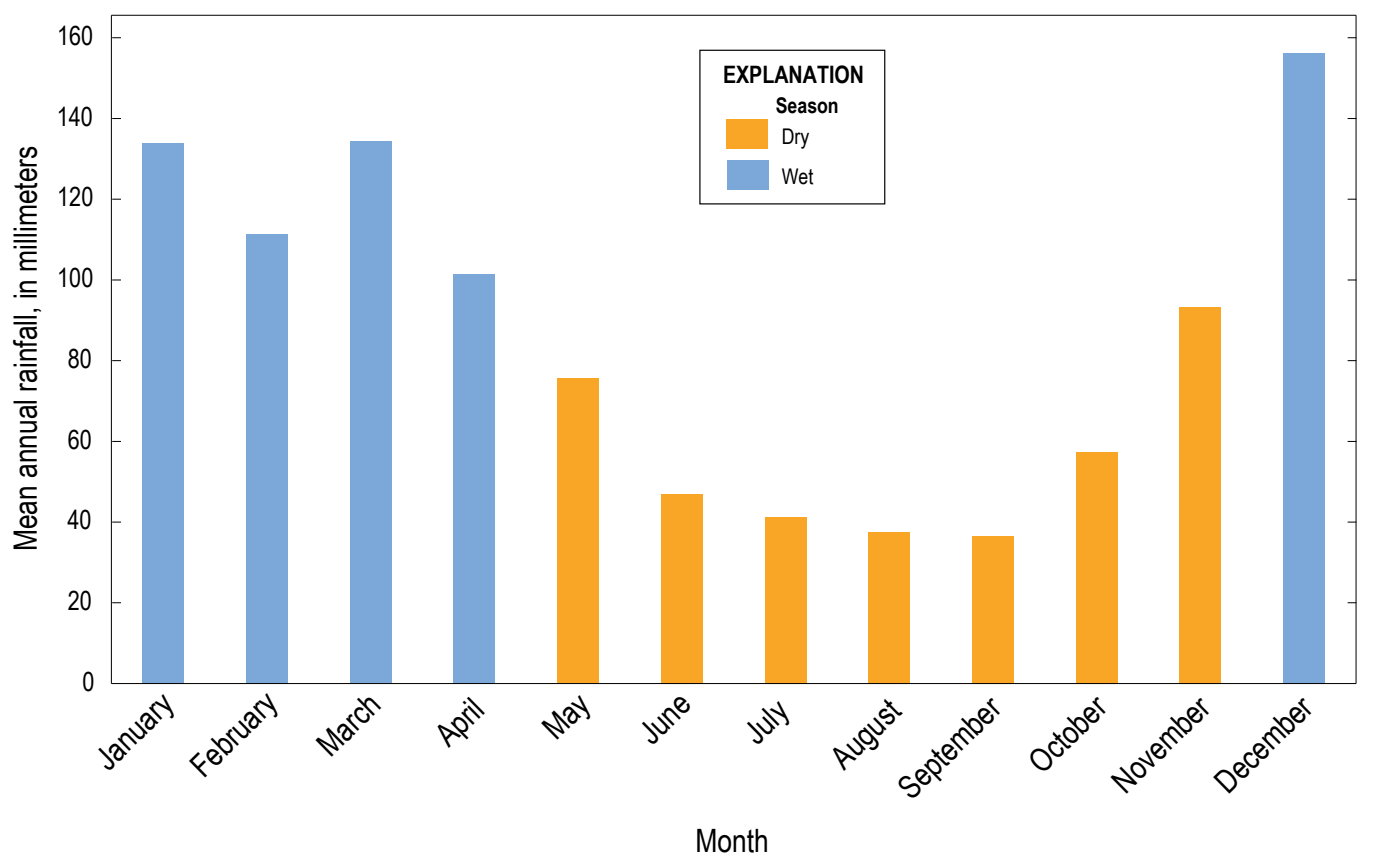

Figure 9. Graph of mean annual rainfall for the period 1978-2007 at the U.S. Geological Survey Ridgeto-Reef (R2R) monitoring site on the island of Moloka'i. Rainfall data from Giambelluca and others (2012).

data, we compiled a complete list of vascular plant species found in each of the plots and adjacent areas at each sampling (appendix).

\section{Photo-Point Sampling}

To capture a more synoptic view of changes in the plant community over time, we established photo points at the ends of each transect and at the upslope side the exclosure which we photographed during each sampling visit (fig. 10). We also used a digital panorama image taken from the east side of the fenced exclosure encompassing both the fenced and unfenced areas, looking upslope along the fence between transects 7 and 8 , to visually show changes in the vegetation inside and outside the fence at each sampling time (fig. 11). Although these images were not used in the quantitative analyses of vegetation change, they provide additional documentation of changes in the vegetation from 2009 to 2014.

\section{Data Analysis}

We hypothesized that feral goat presence or absence in each plot would influence the number of species, the total amount of vegetation cover, and the amount of cover for individual species for the two plots over time. We evaluated changes in species richness at both sites through time by summing the total number of plant species recorded for each plot during each sampling period. We used binary logistic regression (BLR) to assess the significance of differences in total vegetation cover and for cover of individual species over time and among the two plots. For these analyses, each species variable was coded as either 1 (present) or 0 (absent) for each sampled point. This method was used to analyze just 12 of the species detected in the plots because the other species were recorded only very rarely (less than 3 percent maximum cover), and to evaluate change in total plant cover (all species combined versus bare ground). BLR was used to test for differences over time within a treatment group (in other words, for each of the two plots, $\mathrm{K} 1$ [unfenced] and $\mathrm{K} 2$ [fenced]), as well as within the two treatment types, with comparisons made between the April 2009 and April 2014 sampling periods (at the end of the wet season), and between the December 2009 and December 2012 sampling periods (at the end of the dry season).

\section{Results}

\section{Total Vegetation Change Over Time}

The fence surrounding plot $\mathrm{K} 2$ has protected the vegetation in this exclosure from goats since December 2008. Within the exclosure there has been a total lack of browsing or other related signs of goats since the time it was constructed. This site 

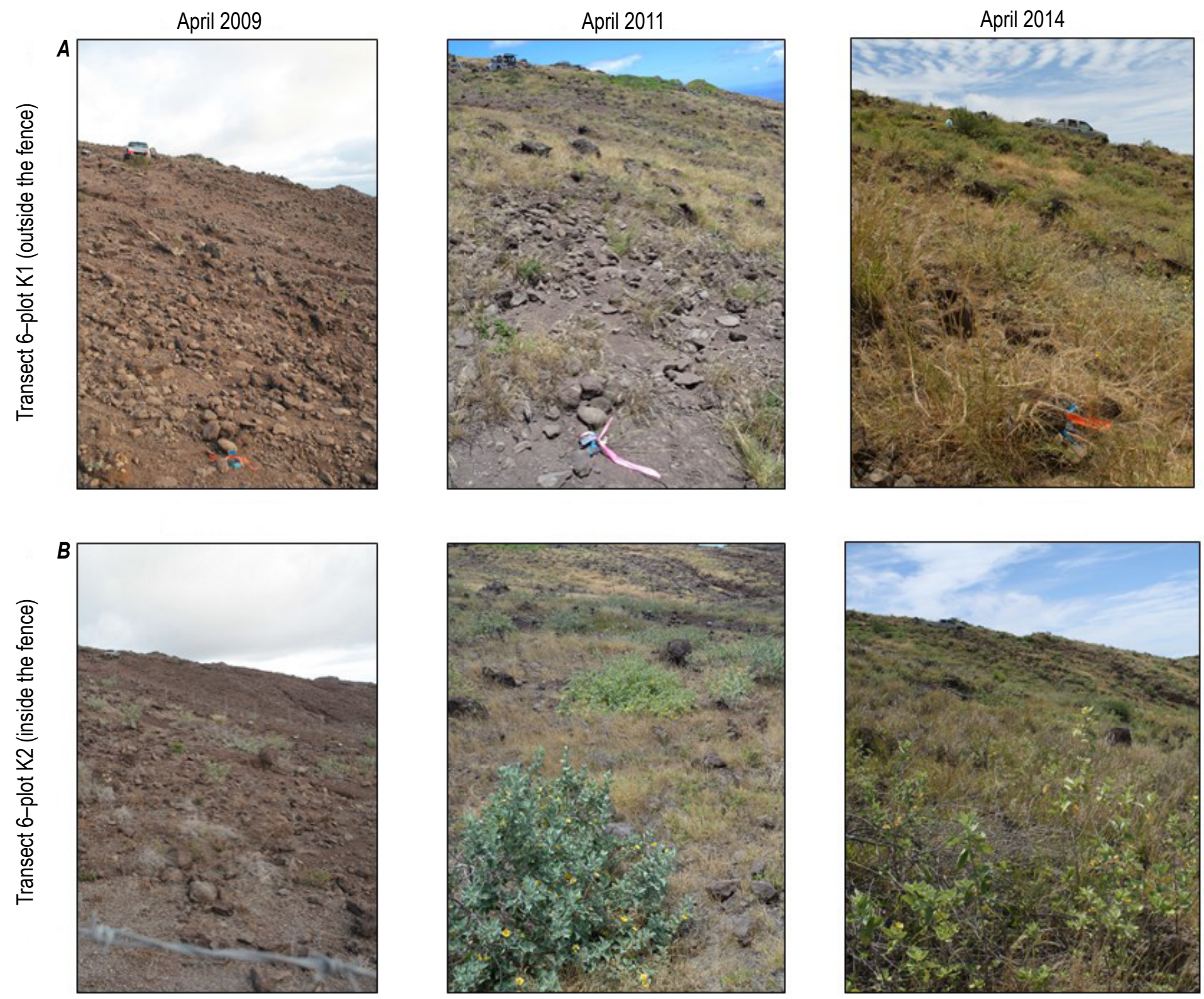

Figure 10. Photo-point series taken on transect 6 facing east in $(A)$ plot $\mathrm{K} 1$ outside the fence, and on transect 6 facing east in $(B)$ plot $\mathrm{K} 2$ inside the fence.

provides a reference condition for no goat impacts when making comparisons with vegetation change outside the fence, which was subject to continuing goat presence, although this area experienced different levels of browsing during the course of the study. Total vegetation cover for both plots through time is shown in table 1 and figures 12 and 13 . Initial vegetation cover at $\mathrm{K} 1$ and $\mathrm{K} 2$ following the construction of the fence at K2 in December 2008, was less than 1 percent by visual inspection. At the end of the wet season in April 2009, there was slightly more vegetation inside the fence in K2 (27.6 percent cover) than outside in K1 (22.9 percent). This same pattern was seen in the April 2010 results with 24.9 percent cover in K2 versus 19.2 percent outside the fence in K1. However, in 2011, the April sampling data showed a dramatic increase in vegetation to more than 50 percent cover in both plots, with the higher value outside the fence in plot K1 (53.6 percent), as compared to 51.1 percent inside the fence in $\mathrm{K} 2$. Although there was a reduced amount of total vegetation cover in both plots when they were sampled in April 2012 (K1 had 36.7 percent and K2 had 26.1 percent), vegetation cover increased in 2013 and 2014, but again with the plot outside the fence showing much more total vegetation cover than inside ( 76.8 percent cover in $\mathrm{K} 1$ and 54.5 percent in K2 for 2014), as shown in table 1 and figure 12.

We found a seasonal difference in total vegetation cover throughout the monitoring period. When we sampled in December at the end of the dry season, vegetation cover was less than 5 percent in both plots during 2009, but had increased to greater 

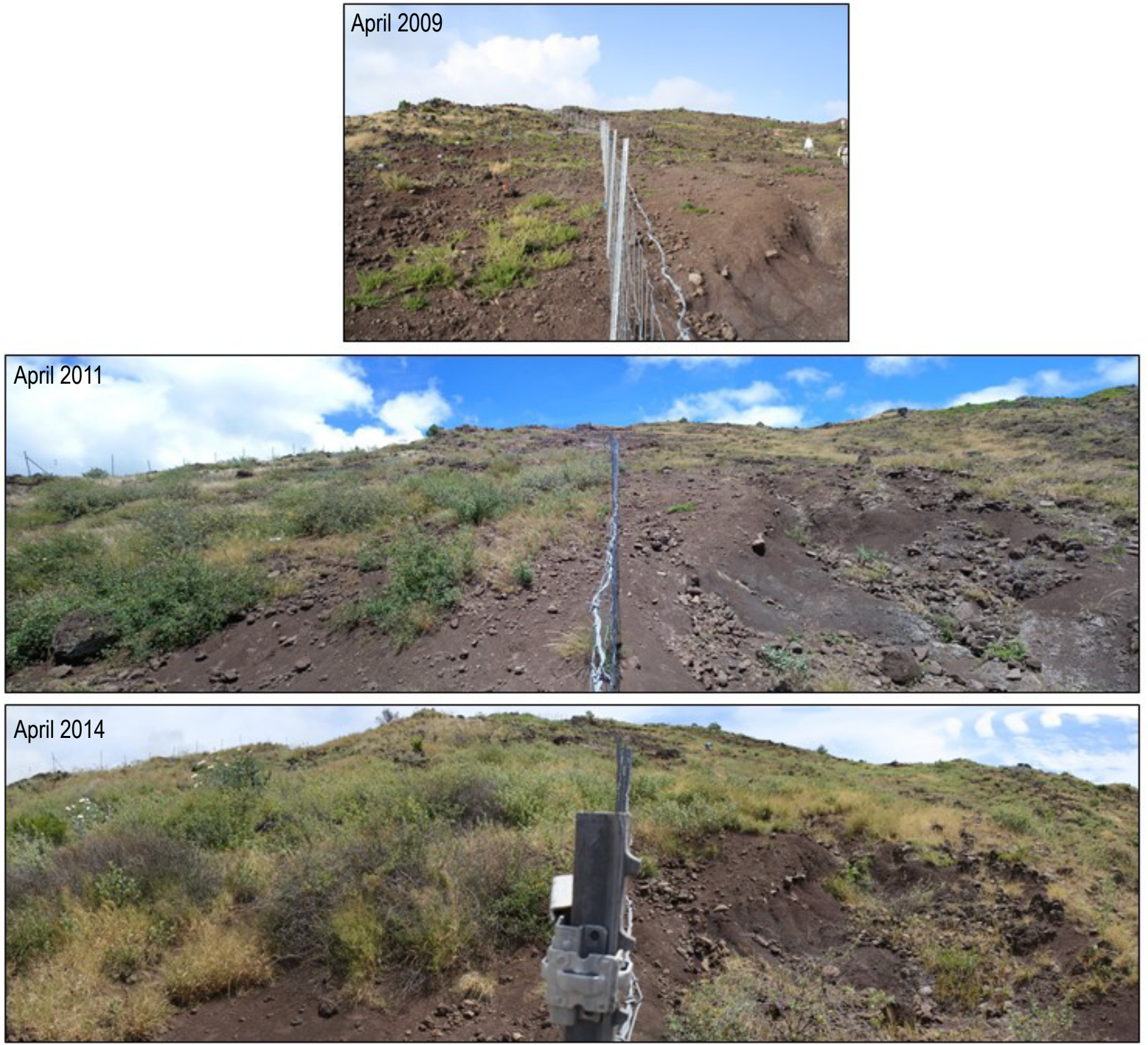

Figure 11. Upslope views of the U.S. Geological Survey Ridge-to-Reef (R2R) study site on the island of Moloka'i in 2009, 2011, and 2014. Plot K2 (inside fenced exclosure) on the left and plot K1 (outside the fence) on the right.

than 10 percent for both plots in 2012 (table 1; fig. 13). During the December 2012 sampling period, there was slightly more vegetation in $\mathrm{K} 1$ outside the fence than was found in $\mathrm{K} 2$ inside the fence, but still at much lower cover values than seen during the previous April sampling periods.

\section{Changes in Species Richness}

There was a large difference in the number of species found in each of the two plots when they were sampled. December sampling (2009 and 2012) yielded a maximum of
4 species in the unfenced $\mathrm{K} 1$ plot and 10 species in the fenced $\mathrm{K} 2$ plot (fig. 14). A similar plot difference was seen in the results from the April sampling periods (fig. 15). For the April sampling period, which is at the end of the wet season when more plant species - including annuals - would be expected to be found, there were generally more species found within the fenced plot than outside the fence. However, this was not as strong of a difference as seen in December, and in one year (2013), slightly more species were found in April outside the fence in plot $\mathrm{K} 1$.

In the pooled December sampling periods, 7 plant species were recorded in plot $\mathrm{K} 1$ and 13 species in plot $\mathrm{K} 2$ (table 2). 


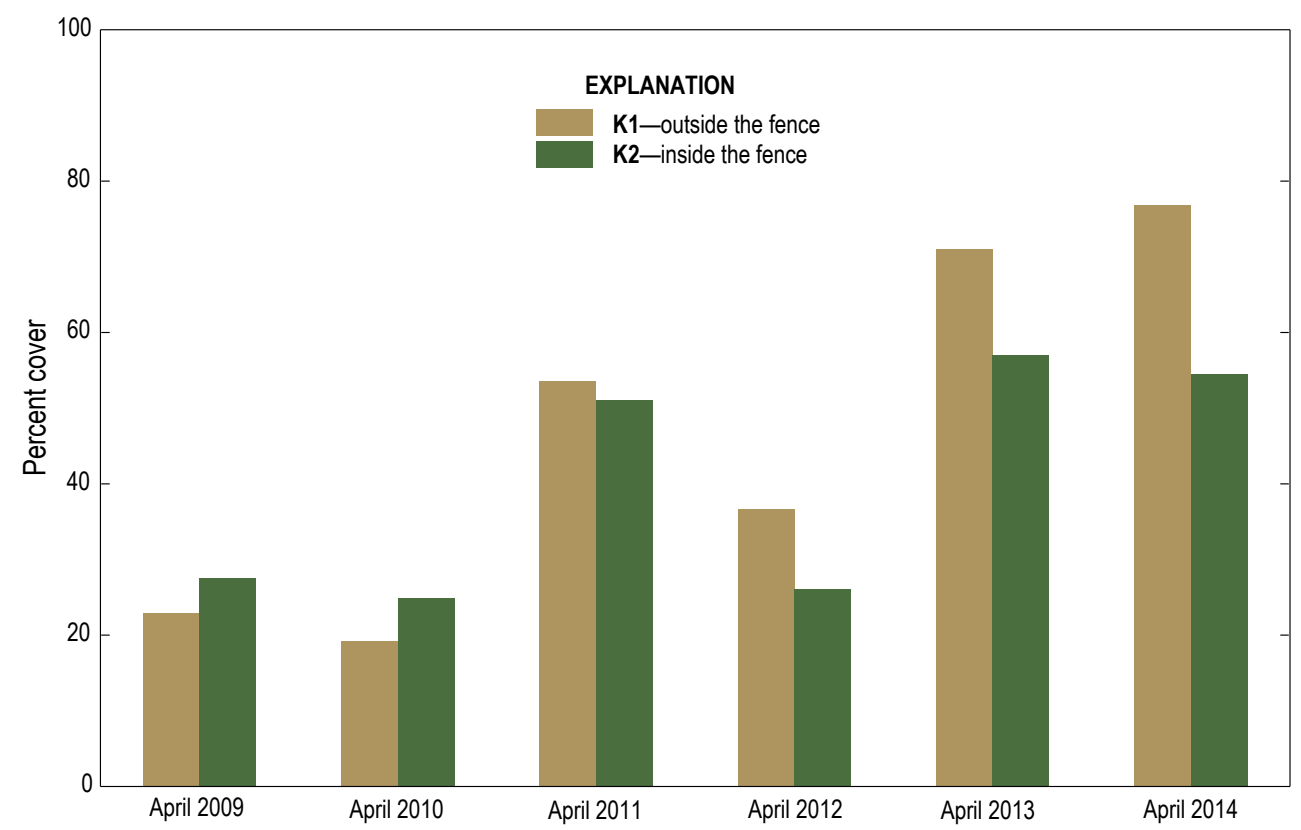

Figure 12. Graph of total vegetation cover for plot $\mathrm{K} 1$ (outside the fence) and $\mathrm{K} 2$ (inside the fence) during the April sampling periods from 2009 to 2014.

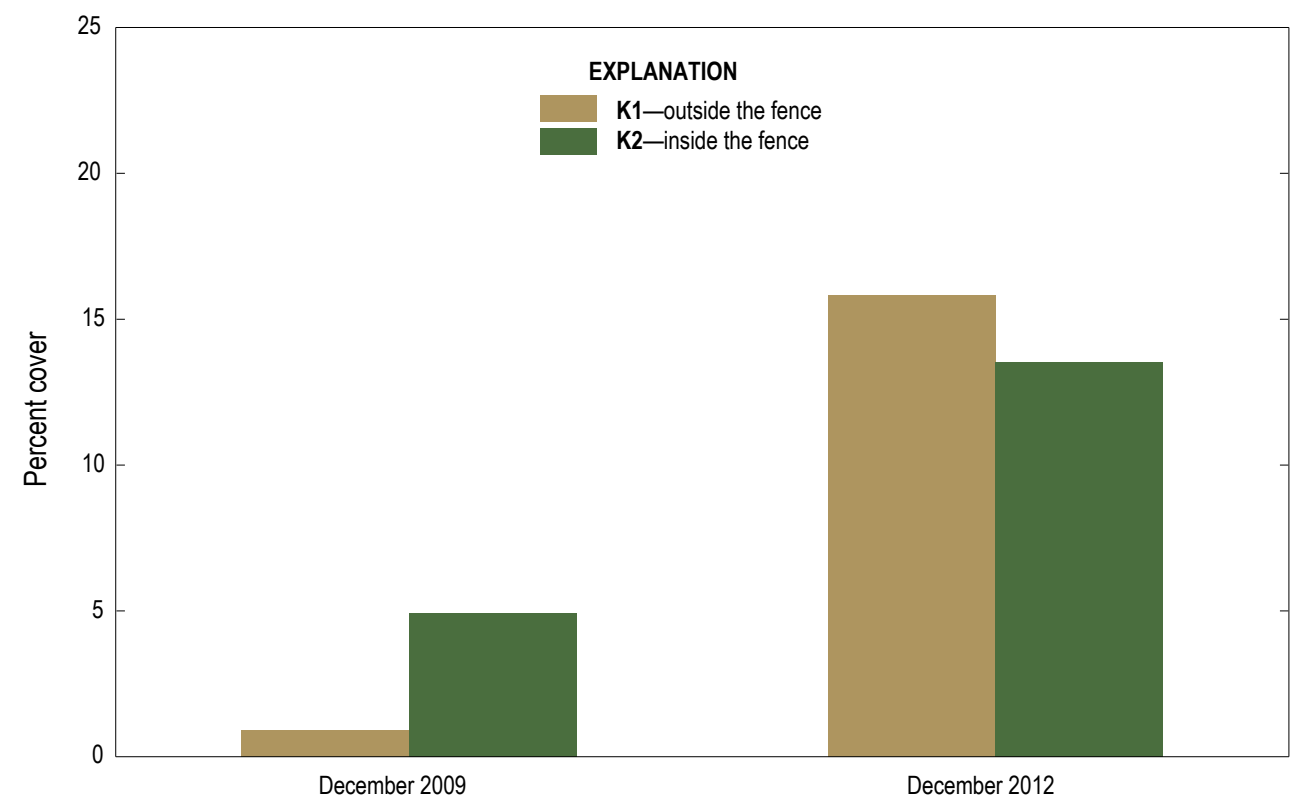

Figure 13. Graph of total vegetation cover for plot K1 (outside the fence) and K2 (inside the fence) during the December sampling periods in 2009 and 2012. 


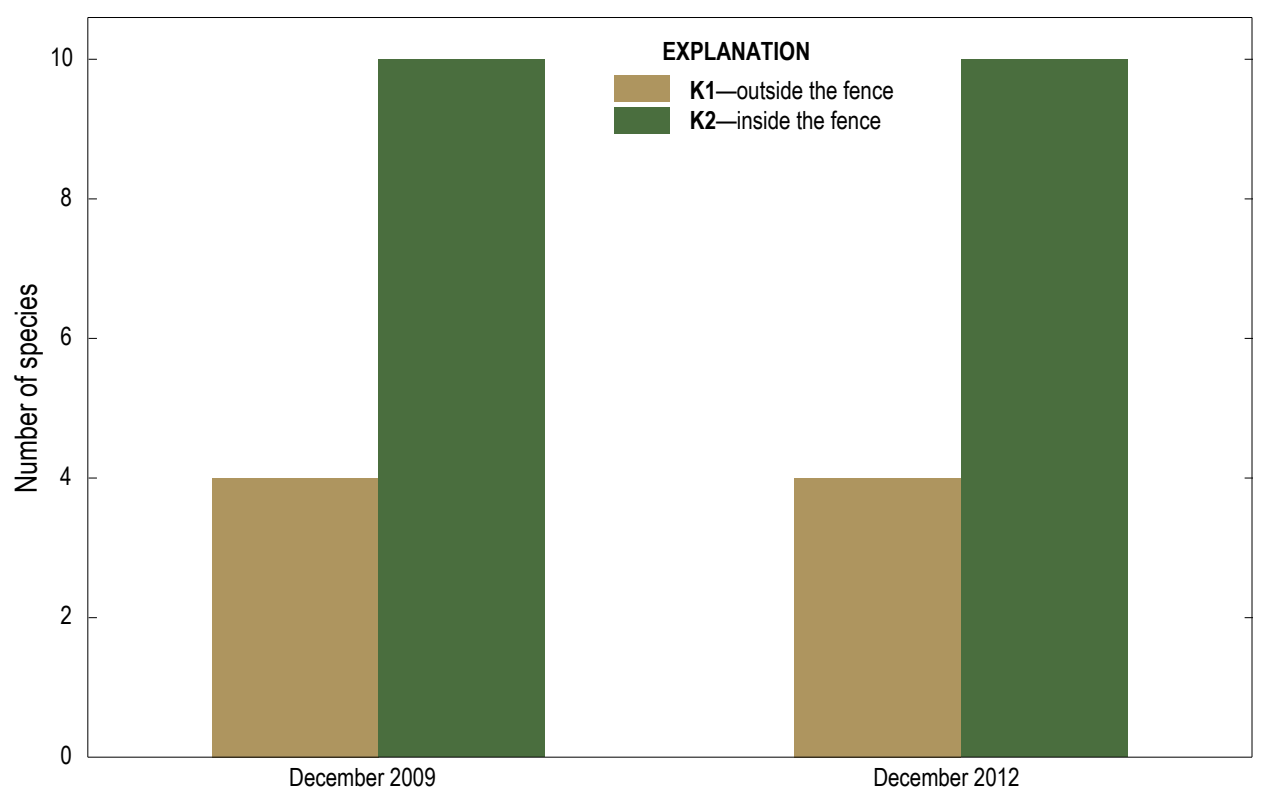

Figure 14. Graph showing the number of plant species recorded within plots K1 and K2 in the U.S. Geological Survey Ridge-to-Reef Moloka'i study area during the December sampling periods.

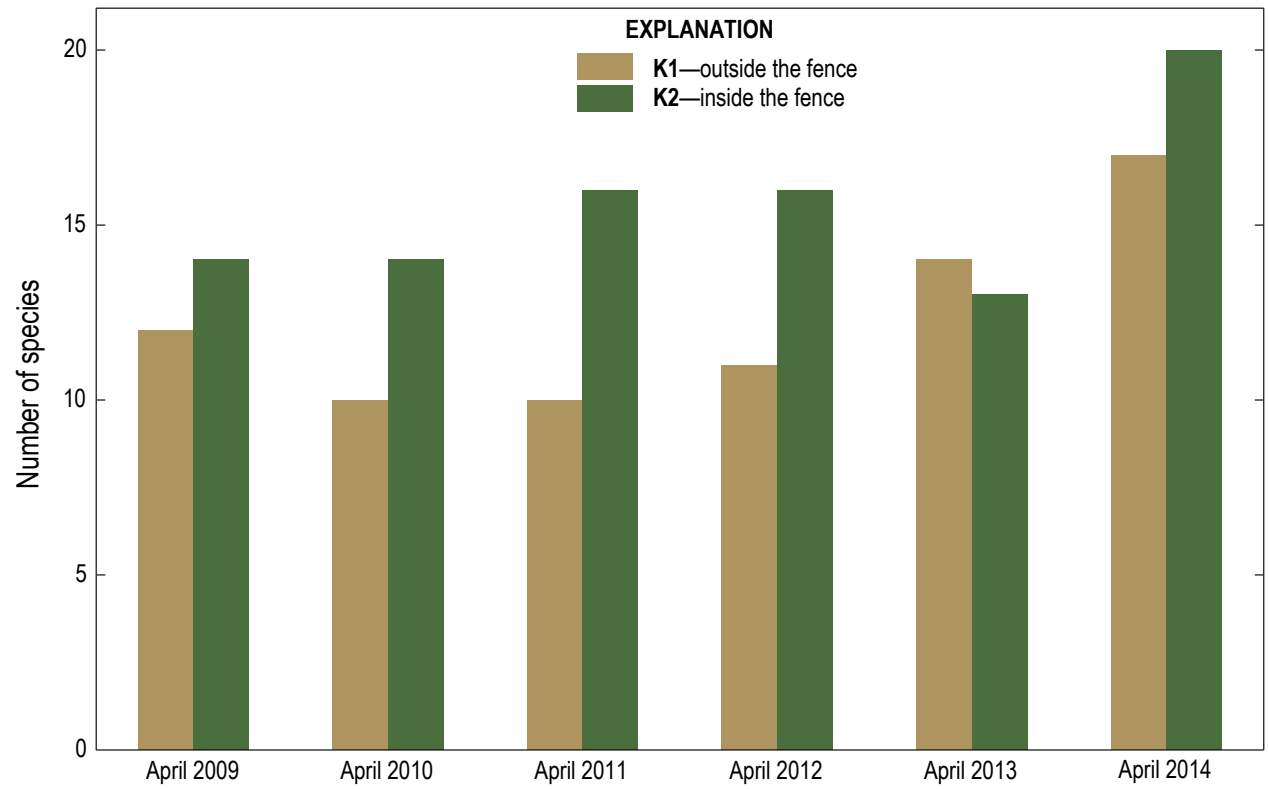

Figure 15. Graph showing the number of plant species recorded within plots K1 and K2 in the U.S. Geological Survey Ridge-to-Reef Moloka'i study area during the April sampling periods. 
Table 2. Percent cover for species recorded in plots $\mathrm{K} 1$ and $\mathrm{K} 2$ during the December sampling periods. Species highlighted in grey had cover values greater than 3 percent for at least one sampling period.

[CenEch, Cenchrus echinatus; CynDac, Cynodon dactylon; LanCam, Lantana camara; AgeAde, Ageratina adenophora; AscPhy, Asclepias physocarpa; BidPil, Bidens pilosa; CheOah, Chenopodium oahuense; GreRob, Grevillea robusta; MelRep, Melinis repens; PhyOct, Phytolacca octandra; AmaSpi, Amaranthus spinosus; DysCar, Dysphania carinata; EupHir, Euphorbia hirta; SidFal, Sida fallax; SolLin, Solanum linnaeanum; TriPro, Tridax procumbens]

\begin{tabular}{lcccc}
\hline \multirow{2}{*}{$\begin{array}{c}\text { Species } \\
\text { code }\end{array}$} & \multicolumn{2}{c}{ December 2009 } & \multicolumn{2}{c}{ December 2012 } \\
\cline { 2 - 3 } \cline { 5 - 5 } & Site K1 & Site K2 & Site K1 & Site K2 \\
\hline CenEch & 0.0 & 0.0 & 0.1 & 0.0 \\
CynDac & 0.0 & 0.0 & 0.7 & 0.0 \\
LanCam & 0.0 & 0.0 & 0.2 & 0.0 \\
\hline \multicolumn{5}{c}{ Species only found in K1 } \\
\hline AgeAde & 0.0 & 0.0 & 0.0 & 0.1 \\
AscPhy & 0.0 & 0.0 & 0.0 & 0.1 \\
BidPil & 0.0 & 0.1 & 0.0 & 0.0 \\
CheOah & 0.0 & 0.0 & 0.0 & 3.5 \\
GreRob & 0.0 & 0.0 & 0.0 & 0.5 \\
MelRep & 0.0 & 0.1 & 0.0 & 3.0 \\
PhyOct & 0.0 & 0.1 & 0.0 & 0.0 \\
\hline & Species found in both K1 and K2 & \\
\hline AmaSpi & 0.1 & 1.3 & 0.0 & 0.2 \\
DysCar & 0.2 & 0.2 & 0.0 & 0.0 \\
EupHir & 0.1 & 0.7 & 0.0 & 0.4 \\
SidFal & 0.0 & 1.6 & 15.3 & 3.5 \\
SolLin & 0.0 & 0.1 & 0.0 & 0.4 \\
TriPro & 0.0 & 0.4 & 0.0 & 2.5 \\
\hline
\end{tabular}

Three species were only found in plot K1, seven species were only found inside the fenced plot K2, and another six species were found in both $\mathrm{K} 1$ and $\mathrm{K} 2$. For the pooled April sampling periods, a total of 20 species were recorded in plot $\mathrm{K} 1$ and 32 species in the fenced plot K2. Three of these plants were only found in plot K1, 15 species were found only in plot K2, and 17 species were recorded in both plots at least one time during the surveys (tables 3,4 ).

\section{Differences in Cover for Individual Species}

Thirty-five plant species were recorded at least once during the sampling of the two plots (tables 5, 6; appendix). Seven species were native ( 4 endemic and 3 indigenous), and 28 were alien species. The appendix lists 11 more species that were found in the two plots but not recorded along the sampling transects. Most plant species had low vegetation cover and only 11 species had greater than 3 percent cover (table 5). The other species were found only occasionally in one or both of the plots, or found just one or two times over the total sampling period. We recorded all 35 species that appeared one or more times during the wetter April sampling period, but a maximum of only 16 species were present during the drier season in December. Species absent in December were mostly annual grasses and herbs, which did not survive to the end of the dry season.

Chenopodium oahuense (CheOah) (fig. 16), a native shrub, was only found during the sampling along transects in plot K2 within the fence; it was absent in April 2009 and 2010 but comprised more than 2 percent cover after April 2012 (table 5). This shrub species persisted at a higher cover level even after the end of the dry season in 2012, when it was recorded at 3.5 percent. Although a few individuals of Chenopodium oahuense were found outside the fence after 2012, all of them were young seedlings or small saplings that had been browsed, presumably by goats. None of these individuals were recorded along the transects at any time in plot K1 outside the fence. Melinis repens (MelRep), an alien grass species, and the alien herb, Tridax procumbens (TriPro), were found mainly in plot $\mathrm{K} 2$ and increased in cover in this protected area over time (table 5). Melinis showed an increase in cover from less than 1 percent in April 2009 to more than 18 percent in 2014 (fig. 17). Tridax went from less than 1 percent cover in April 2009 to more than 3 percent in April 2013 (fig. 18), with a similar change in cover during the December sampling.

The greatest changes were seen for the native grass Panicum fauriei var. fauriei (PanFau) (fig. 19), and the widespread native shrub Sida fallax (SidFal) (fig. 20), with both species having less than 1 percent cover in April 2009, but increasing substantially in both plots through the April 2014 sampling period (figs. 21, 22; table 5). Although Sida showed a similar increase in both plots from December 2009 until December 2012, the annual native grass Panicum was absent from both plots during each of the December sampling dates. A different pattern was seen with the annual alien grasses Festuca myuros (FesMyu) and Bromus rubens (BroRub). Although both species were found in each of the plots, they were consistently more abundant in the unfenced $\mathrm{K} 1$ plot where there was continued goat browsing, particularly after 2009 (fig. 23; table 5). Another annual herb, Dysphania carinata (DysCar), was originally found with relatively high cover along the transects inside (15.9 percent) and outside (7.6 percent) the fence in 2009, but its cover decreased sharply after 2010 to the point that it was not recorded in either plot during the April 2014 sampling (fig. 24; table 5). D. carinata was very rare during the December 2009 sampling and absent in December 2012, and the annual grasses Festuca and Bromus were totally absent during the two December sampling periods. The remaining species in table 5 were quite rare and did not show any clear spatial or temporal patterns in their recorded cover.

The binary logistic regression (BLR) analysis results showed that the interval term was highly significant for all species that could be modeled (table 7). The interval variable 
Table 3. Percent cover for species recorded only in plot K1 or K2 during the April sampling periods. Species highlighted in grey had cover values greater than 3 percent for at least one sampling period.

[BoeCoc, Boerhavia coccinea; LanCam, Lantana camara; MyoSan, Myoporum sandwicense; AgeAde, Ageratina adenophora; ArgGla, Argemone glauca var. glauca; AscPhy, Asclepias physocarpa; CenEch, Cenchrus echinatus; CheOah, Chenopodium oahuense; DodVis, Dodonaea viscosa; DorDec, Doryopteris decipiens; GalPar, Galinsoga parviflora; GreRob, Grevillea robusta; LepDub, Leptochloa dubia; MelMin, Melinis minutiflora; PhyOct, Phytolacca octandra; PitAus, Pityrogramma austroamericana; SenSyl, Senecio sylvaticus; SilGal, Silene gallica]

\begin{tabular}{|c|c|c|c|c|c|c|c|c|c|c|c|c|}
\hline \multirow{2}{*}{$\begin{array}{l}\text { Species } \\
\text { code }\end{array}$} & \multicolumn{2}{|c|}{ April 2009} & \multicolumn{2}{|c|}{ April 2010} & \multicolumn{2}{|c|}{ April 2011} & \multicolumn{2}{|c|}{ April 2012} & \multicolumn{2}{|c|}{ April 2013} & \multicolumn{2}{|c|}{ April 2014} \\
\hline & Site K1 & Site K2 & Site K1 & Site K2 & Site K1 & Site K2 & Site K1 & Site K2 & Site K1 & Site K2 & Site K1 & Site K2 \\
\hline \multicolumn{13}{|c|}{ Species only found in K1 } \\
\hline LanCam & 0.0 & 0.0 & 0.1 & 0.0 & 0.3 & 0.0 & 0.3 & 0.0 & 0.2 & 0.0 & 0.4 & 0.0 \\
\hline MyoSan & 0.0 & 0.0 & 0.0 & 0.0 & 0.0 & 0.0 & 0.0 & 0.0 & 0.0 & 0.0 & 0.1 & 0.0 \\
\hline \multicolumn{13}{|c|}{ Species only found in K2 } \\
\hline ArgGla & 0.0 & 0.0 & 0.0 & 0.0 & 0.0 & 0.0 & 0.0 & 0.0 & 0.0 & 0.0 & 0.0 & 0.1 \\
\hline AscPhy & 0.0 & 0.0 & 0.0 & 0.0 & 0.0 & 0.0 & 0.0 & 0.4 & 0.0 & 0.0 & 0.0 & 0.0 \\
\hline CenEch & 0.0 & 0.0 & 0.0 & 0.1 & 0.0 & 0.0 & 0.0 & 0.3 & 0.0 & 0.0 & 0.0 & 0.0 \\
\hline CheOah & 0.0 & 0.0 & 0.0 & 0.0 & 0.0 & 1.6 & 0.0 & 3.8 & 0.0 & 2.6 & 0.0 & 2.3 \\
\hline DodVis & 0.0 & 0.0 & 0.0 & 0.0 & 0.0 & 0.0 & 0.0 & 0.0 & 0.0 & 0.0 & 0.0 & 0.3 \\
\hline MelMin & 0.0 & 0.0 & 0.0 & 0.0 & 0.0 & 0.0 & 0.0 & 0.0 & 0.0 & 0.0 & 0.0 & 2.3 \\
\hline PhyOct & 0.0 & 0.0 & 0.0 & 0.2 & 0.0 & 0.0 & 0.0 & 0.0 & 0.0 & 0.0 & 0.0 & 0.0 \\
\hline PitAus & 0.0 & 0.2 & 0.0 & 0.0 & 0.0 & 0.1 & 0.0 & 0.0 & 0.0 & 0.0 & 0.0 & 0.0 \\
\hline SenSyl & 0.0 & 0.1 & 0.0 & 0.0 & 0.0 & 0.1 & 0.0 & 0.0 & 0.0 & 0.0 & 0.0 & 0.0 \\
\hline SilGal & 0.0 & 0.0 & 0.0 & 0.0 & 0.0 & 0.0 & 0.0 & 0.0 & 0.0 & 0.0 & 0.0 & 0.1 \\
\hline
\end{tabular}

Table 4. Percent cover for species recorded in both plot K1 and K2 during the April sampling periods. Species highlighted in grey had cover values greater than 3 percent for at least one sampling period.

[AmaSpi, Amaranthus spinosus; AnaArv, Anagallis arvensis; BidPil, Bidens pilosa; BroRub, Bromus rubens; ConBon, Conyza bonariensis; CynDac, Cynodon dactylon; DauPus, Daucus pusillus; DysCar, Dysphania carinata; EupHir, Euphorbia hirta; FesMyu, Festuca myuros; HypRad, Hypochoeris radicata; MelRep, Melinis repens; PanFau, Panicum fauriei var. fauriei; PorOle, Portulaca oleracea; SidFal, Sida fallax; SolLin, Solanum linnaeanum; TriPro, Tridax procumbens ]

\begin{tabular}{|c|c|c|c|c|c|c|c|c|c|c|c|c|}
\hline \multirow{2}{*}{$\begin{array}{l}\text { Species } \\
\text { code }\end{array}$} & \multicolumn{2}{|c|}{ April 2009} & \multicolumn{2}{|c|}{ April 2010} & \multicolumn{2}{|c|}{ April 2011} & \multicolumn{2}{|c|}{ April 2012} & \multicolumn{2}{|c|}{ April 2013} & \multicolumn{2}{|c|}{ April 2014} \\
\hline & Site K1 & Site K2 & Site K1 & Site K2 & Site K1 & Site K2 & Site K1 & Site K2 & Site K1 & Site K2 & Site K1 & Site K2 \\
\hline AmaSpi & 1.2 & 4.2 & 0.4 & 3.4 & 1.7 & 4.6 & 0.3 & 1.1 & 0.3 & 2.2 & 0.8 & 0.4 \\
\hline BidPil & 1.1 & 3.6 & 0.7 & 1.6 & 2.3 & 4.0 & 0.3 & 0.4 & 0.8 & 0.5 & 8.4 & 1.5 \\
\hline BroRub & 1.3 & 2.0 & 3.7 & 6.4 & 8.4 & 7.3 & 1.8 & 0.6 & 6.8 & 1.5 & 3.2 & 0.5 \\
\hline ConBon & 0.0 & 0.0 & 0.0 & 0.0 & 0.0 & 0.0 & 0.0 & 0.0 & 0.0 & 0.0 & 0.1 & 0.1 \\
\hline DauPus & 0.3 & 0.0 & 0.7 & 0.0 & 0.9 & 0.1 & 0.1 & 0.0 & 0.3 & 0.0 & 0.1 & 0.0 \\
\hline DysCar & 15.9 & 7.6 & 11.6 & 2.0 & 5.7 & 0.0 & 0.2 & 0.0 & 1.3 & 0.6 & 0.0 & 0.0 \\
\hline EupHir & 0.0 & 0.0 & 0.2 & 0.8 & 0.3 & 0.5 & 0.4 & 0.8 & 0.2 & 0.1 & 3.3 & 1.1 \\
\hline FesMyu & 4.6 & 4.2 & 2.7 & 3.9 & 23.0 & 17.7 & 0.8 & 1.1 & 11.8 & 5.8 & 44.4 & 14.5 \\
\hline HypRad & 0.1 & 0.0 & 0.0 & 0.0 & 0.0 & 0.0 & 0.0 & 0.0 & 0.0 & 0.0 & 0.0 & 0.1 \\
\hline SolLin & 0.0 & 0.0 & 0.0 & 0.0 & 0.0 & 0.3 & 0.0 & 0.4 & 0.0 & 0.0 & 0.2 & 0.0 \\
\hline TriPro & 0.0 & 0.4 & 0.0 & 0.8 & 0.0 & 1.0 & 0.0 & 1.9 & 0.1 & 3.1 & 0.4 & 1.8 \\
\hline
\end{tabular}


Table 5. Percent cover for all species recorded in plots K1 and K2 for the April sampling periods. Species highlighted in grey had cover values greater than three percent in at least one of the sampling periods.

[AgeAde, Ageratina adenophora; AmaSpi, Amaranthus spinosus; AnaArv, Anagallis arvensis; ArgGla, Argemone glauca var. glauca; AscPhy, Asclepias physocarpa; BidPil, Bidens pilosa; BoeCoc, Boerhavia coccinea; BroRub, Bromus rubens; CenEch, Cenchrus echinatus; CheOah, Chenopodium oahuense; ConBon, Conyza bonariensis; CynDac, Cynodon dactylon; DauPus, Daucus pusillus; DodVis, Dodonaea viscosa; DorDec, Doryopteris decipiens; DysCar, Dysphania carinata; EupHir, Euphorbia hirta; FesMyu, Festuca myuros; GalPar, Galinsoga parviflora; GreRob, Grevillea robusta; hypRad, Hypochoeris radicata; LanCam, Lantana camara; LepDub, Leptochloa dubia; MelMin, Melinis minutiflora; MelRep, Melinis repens; MyoSan, Myoporum sandwicense; PanFau, Panicum fauriei var. fauriei; PhyOct, Phytolacca octandra; PitAus, Pityrogramma austroamericana; PorOle, Portulaca oleracea; SenSyl, Senecio sylvaticus; SidFal, Sida fallax; SilGal, Silene gallica; SolLin, Solanum linnaeanum; TriPro, Tridax procumbens]

\begin{tabular}{|c|c|c|c|c|c|c|c|c|c|c|c|c|}
\hline \multirow{2}{*}{ Species code } & \multicolumn{2}{|c|}{ April 2009} & \multicolumn{2}{|c|}{ April 2010} & \multicolumn{2}{|c|}{ April 2011} & \multicolumn{2}{|c|}{ April 2012} & \multicolumn{2}{|c|}{ April 2013} & \multicolumn{2}{|c|}{ April 2014} \\
\hline & Site K1 & Site K2 & Site K1 & Site K2 & Site K1 & Site K2 & Site K1 & Site K2 & Site K1 & Site K2 & Site K1 & Site K2 \\
\hline AgeAde & 0.0 & 0.0 & 0.0 & 0.0 & 0.0 & 0.0 & 0.0 & 0.2 & 0.0 & 0.1 & 0.0 & 0.0 \\
\hline AmaSpi & 1.2 & 4.2 & 0.4 & 3.4 & 1.7 & 4.6 & 0.3 & 1.1 & 0.3 & 2.2 & 0.8 & 0.4 \\
\hline AnaArv & 0.0 & 0.1 & 0.0 & 0.0 & 0.0 & 0.0 & 0.0 & 0.0 & 0.0 & 0.0 & 0.1 & 0.3 \\
\hline ArgGla & 0.0 & 0.0 & 0.0 & 0.0 & 0.0 & 0.0 & 0.0 & 0.0 & 0.0 & 0.0 & 0.0 & 0.1 \\
\hline AscPhy & 0.0 & 0.0 & 0.0 & 0.0 & 0.0 & 0.0 & 0.0 & 0.4 & 0.0 & 0.0 & 0.0 & 0.0 \\
\hline BidPil & 1.1 & 3.6 & 0.7 & 1.6 & 2.3 & 4.0 & 0.3 & 0.4 & 0.8 & 0.5 & 8.4 & 1.5 \\
\hline BoeCoc & 0.0 & 0.0 & 0.0 & 0.0 & 0.0 & 0.0 & 0.0 & 0.0 & 0.3 & 0.0 & 0.3 & 0.0 \\
\hline BroRub & 1.3 & 2.0 & 3.7 & 6.4 & 8.4 & 7.3 & 1.8 & 0.6 & 6.8 & 1.5 & 3.2 & 0.5 \\
\hline CenEch & 0.0 & 0.0 & 0.0 & 0.1 & 0.0 & 0.0 & 0.0 & 0.3 & 0.0 & 0.0 & 0.0 & 0.0 \\
\hline CheOah & 0.0 & 0.0 & 0.0 & 0.0 & 0.0 & 1.6 & 0.0 & 3.8 & 0.0 & 2.6 & 0.0 & 2.3 \\
\hline ConBon & 0.0 & 0.0 & 0.0 & 0.0 & 0.0 & 0.0 & 0.0 & 0.0 & 0.0 & 0.0 & 0.1 & 0.1 \\
\hline CynDac & 0.0 & 0.0 & 0.0 & 0.0 & 0.0 & 0.0 & 0.8 & 0.0 & 0.3 & 0.0 & 0.8 & 0.2 \\
\hline DauPus & 0.3 & 0.0 & 0.7 & 0.0 & 0.9 & 0.1 & 0.1 & 0.0 & 0.3 & 0.0 & 0.1 & 0.0 \\
\hline DodVis & 0.0 & 0.0 & 0.0 & 0.0 & 0.0 & 0.0 & 0.0 & 0.0 & 0.0 & 0.0 & 0.0 & 0.3 \\
\hline DorDec & 0.0 & 0.0 & 0.0 & 0.1 & 0.0 & 0.0 & 0.0 & 0.0 & 0.0 & 0.0 & 0.0 & 0.0 \\
\hline DysCar & 15.9 & 7.6 & 11.6 & 2.0 & 5.7 & 0.0 & 0.2 & 0.0 & 1.3 & 0.6 & 0.0 & 0.0 \\
\hline EupHir & 0.0 & 0.0 & 0.2 & 0.8 & 0.3 & 0.5 & 0.4 & 0.8 & 0.2 & 0.1 & 3.3 & 1.1 \\
\hline FesMyu & 4.6 & 4.2 & 2.7 & 3.9 & 23.0 & 17.7 & 0.8 & 1.1 & 11.8 & 5.8 & 44.4 & 14.5 \\
\hline GalPar & 0.0 & 0.0 & 0.0 & 0.0 & 0.0 & 0.4 & 0.0 & 0.0 & 0.0 & 0.0 & 0.0 & 0.1 \\
\hline GreRob & 0.0 & 0.0 & 0.0 & 0.0 & 0.0 & 0.3 & 0.0 & 0.1 & 0.0 & 0.5 & 0.0 & 0.4 \\
\hline HypRad & 0.1 & 0.0 & 0.0 & 0.0 & 0.0 & 0.0 & 0.0 & 0.0 & 0.0 & 0.0 & 0.0 & 0.1 \\
\hline LanCam & 0.0 & 0.0 & 0.1 & 0.0 & 0.3 & 0.0 & 0.3 & 0.0 & 0.2 & 0.0 & 0.4 & 0.0 \\
\hline LepDub & 0.0 & 0.0 & 0.0 & 0.0 & 0.0 & 0.0 & 0.0 & 0.1 & 0.0 & 0.0 & 0.0 & 0.0 \\
\hline MelMin & 0.0 & 0.0 & 0.0 & 0.0 & 0.0 & 0.0 & 0.0 & 0.0 & 0.0 & 0.0 & 0.0 & 2.3 \\
\hline MelRep & 0.0 & 0.2 & 0.0 & 0.4 & 0.0 & 0.8 & 0.0 & 4.1 & 0.1 & 7.4 & 1.3 & 18.4 \\
\hline MyoSan & 0.0 & 0.0 & 0.0 & 0.0 & 0.0 & 0.0 & 0.0 & 0.0 & 0.0 & 0.0 & 0.1 & 0.0 \\
\hline PanFau & 0.5 & 8.2 & 1.2 & 5.9 & 25.7 & 23.1 & 28.6 & 9.5 & 56.6 & 41.7 & 20.4 & 13.6 \\
\hline PhyOct & 0.0 & 0.0 & 0.0 & 0.2 & 0.0 & 0.0 & 0.0 & 0.0 & 0.0 & 0.0 & 0.0 & 0.0 \\
\hline PitAus & 0.0 & 0.2 & 0.0 & 0.0 & 0.0 & 0.1 & 0.0 & 0.0 & 0.0 & 0.0 & 0.0 & 0.0 \\
\hline PorOle & 0.1 & 0.3 & 0.0 & 0.2 & 0.0 & 0.0 & 0.0 & 0.0 & 0.0 & 0.0 & 0.0 & 0.0 \\
\hline SenSyl & 0.0 & 0.1 & 0.0 & 0.0 & 0.0 & 0.1 & 0.0 & 0.0 & 0.0 & 0.0 & 0.0 & 0.0 \\
\hline SidFal & 0.1 & 0.4 & 0.1 & 2.8 & 1.7 & 5.0 & 8.0 & 5.6 & 18.8 & 7.8 & 29.6 & 15.0 \\
\hline SilGal & 0.0 & 0.0 & 0.0 & 0.0 & 0.0 & 0.0 & 0.0 & 0.0 & 0.0 & 0.0 & 0.0 & 0.1 \\
\hline SolLin & 0.0 & 0.0 & 0.0 & 0.0 & 0.0 & 0.3 & 0.0 & 0.4 & 0.0 & 0.0 & 0.2 & 0.0 \\
\hline TriPro & 0.0 & 0.4 & 0.0 & 0.8 & 0.0 & 1.0 & 0.0 & 1.9 & 0.1 & 3.1 & 0.4 & 1.8 \\
\hline
\end{tabular}


Table 6. Percent cover for all species recorded in plots K1 and K2 for the December sampling periods. Species highlighted in grey had cover values greater than three percent in at least one of the sampling periods.

[AgeAde, Ageratina adenophora; AmaSpi, Amaranthus spinosus; AnaArv, Anagallis arvensis; ArgGla, Argemone glauca var. glauca; AscPhy, Asclepias physocarpa; BidPil, Bidens pilosa; BoeCoc, Boerhavia coccinea; BroRub, Bromus rubens; CenEch, Cenchrus echinatus; CheOah, Chenopodium oahuense; ConBon, Conyza bonariensis; CynDac, Cynodon dactylon; DauPus, Daucus pusillus; DodVis, Dodonaea viscosa; DorDec, Doryopteris decipiens; DysCar, Dysphania carinata; EupHir, Euphorbia hirta; FesMyu, Festuca myuros; GalPar, Galinsoga parviflora; GreRob, Grevillea robusta; hypRad, Hypochoeris radicata; LanCam, Lantana camara; LepDub, Leptochloa dubia; MelMin, Melinis minutiflora; MelRep, Melinis repens; MyoSan, Myoporum sandwicense; PanFau, Panicum fauriei var. fauriei; PhyOct, Phytolacca octandra; PitAus, Pityrogramma austroamericana; PorOle, Portulaca oleracea; SenSyl, Senecio sylvaticus; SidFal, Sida fallax; SilGal, Silene gallica; SolLin, Solanum linnaeanum; TriPro, Tridax procumbens]

\begin{tabular}{|c|c|c|c|c|c|c|c|c|c|}
\hline \multirow{2}{*}{$\begin{array}{l}\text { Species } \\
\text { code }\end{array}$} & \multicolumn{2}{|c|}{ December 2009} & \multicolumn{2}{|c|}{ December 2012} & \multirow{2}{*}{$\begin{array}{l}\text { Species } \\
\text { code }\end{array}$} & \multicolumn{2}{|c|}{ December 2009} & \multicolumn{2}{|c|}{ December 2012} \\
\hline & Site K1 & Site K2 & Site K1 & Site K2 & & Site K1 & Site K2 & Site K1 & Site K2 \\
\hline AgeAde & 0.0 & 0.0 & 0.0 & 0.1 & GalPar & 0.0 & 0.0 & 0.0 & 0.0 \\
\hline AnaArv & 0.0 & 0.0 & 0.0 & 0.0 & HypRad & 0.0 & 0.0 & 0.0 & 0.0 \\
\hline ArgGla & 0.0 & 0.0 & 0.0 & 0.0 & LanCam & 0.0 & 0.0 & 0.2 & 0.0 \\
\hline AscPhy & 0.0 & 0.0 & 0.0 & 0.1 & LepDub & 0.0 & 0.0 & 0.0 & 0.0 \\
\hline BoeCoc & 0.0 & 0.0 & 0.0 & 0.0 & MelRep & 0.0 & 0.1 & 0.0 & 3.0 \\
\hline BroRub & 0.0 & 0.0 & 0.0 & 0.0 & MyoSan & 0.0 & 0.0 & 0.0 & 0.0 \\
\hline CenEch & 0.0 & 0.0 & 0.1 & 0.0 & PanFau & 0.0 & 0.0 & 0.0 & 0.0 \\
\hline CheOah & 0.0 & 0.0 & 0.0 & 3.5 & PhyOct & 0.0 & 0.1 & 0.0 & 0.0 \\
\hline ConBon & 0.0 & 0.0 & 0.0 & 0.0 & PitAus & 0.0 & 0.0 & 0.0 & 0.0 \\
\hline DysCar & 0.2 & 0.2 & 0.0 & 0.0 & SolLin & 0.0 & 0.1 & 0.0 & 0.4 \\
\hline EupHir & 0.1 & 0.7 & 0.0 & 0.4 & TriPro & 0.0 & 0.4 & 0.0 & 2.5 \\
\hline
\end{tabular}

Table 7. Summary of the results from binary logistic regression analysis for plant species that could be analyzed and modeled.

[BidPil, Bidens pilosa; BroRub, Bromus rubens; FesMyu, Festuca myuros; PanFau, Panicum fauriei var. fauriei]

\begin{tabular}{|c|c|c|c|c|}
\hline Model & P-value & Coefficient & P-value & Coefficient \\
\hline & \multicolumn{2}{|c|}{ Interval (April 2009-2014) } & \multicolumn{2}{|c|}{ Interaction (interval ${ }^{*}$ plot) } \\
\hline Any plant & 0.000 & 2.410 & 0.000 & -1.265 \\
\hline BidPil & 0.000 & 1.120 & 0.000 & -3.022 \\
\hline BroRub & 0.001 & 0.953 & 0.000 & -2.312 \\
\hline FesMyu & 0.000 & 2.811 & 0.000 & -1.469 \\
\hline \multirow[t]{2}{*}{ PanFau } & 0.000 & 3.932 & 0.000 & -3.367 \\
\hline & \multicolumn{2}{|c|}{ Interval (December 2009-2012) } & \multicolumn{2}{|c|}{ Interaction (interval ${ }^{*}$ plot) } \\
\hline Any plant & 0.000 & 3.011 & 0.000 & -1.902 \\
\hline
\end{tabular}


Figure 16. Photograph showing the native shrub Chenopodium oahuense growing inside the fenced area in plot K2.
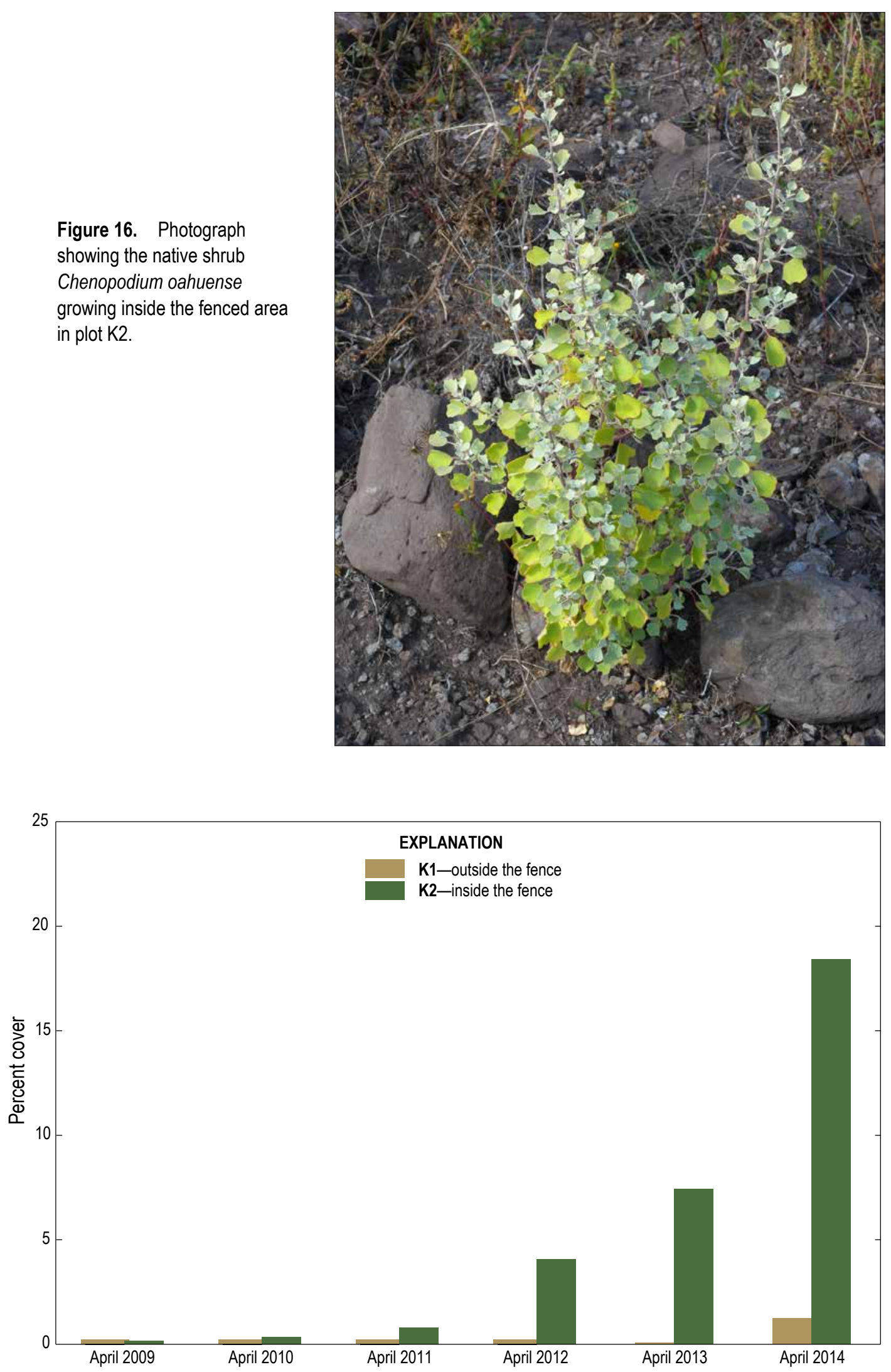

Figure 17. Graph showing percent cover of Melinis repens for the April sampling periods within plots K1 and K2 in the U.S. Geological Survey Ridge-to-Reef Moloka'i study area. 


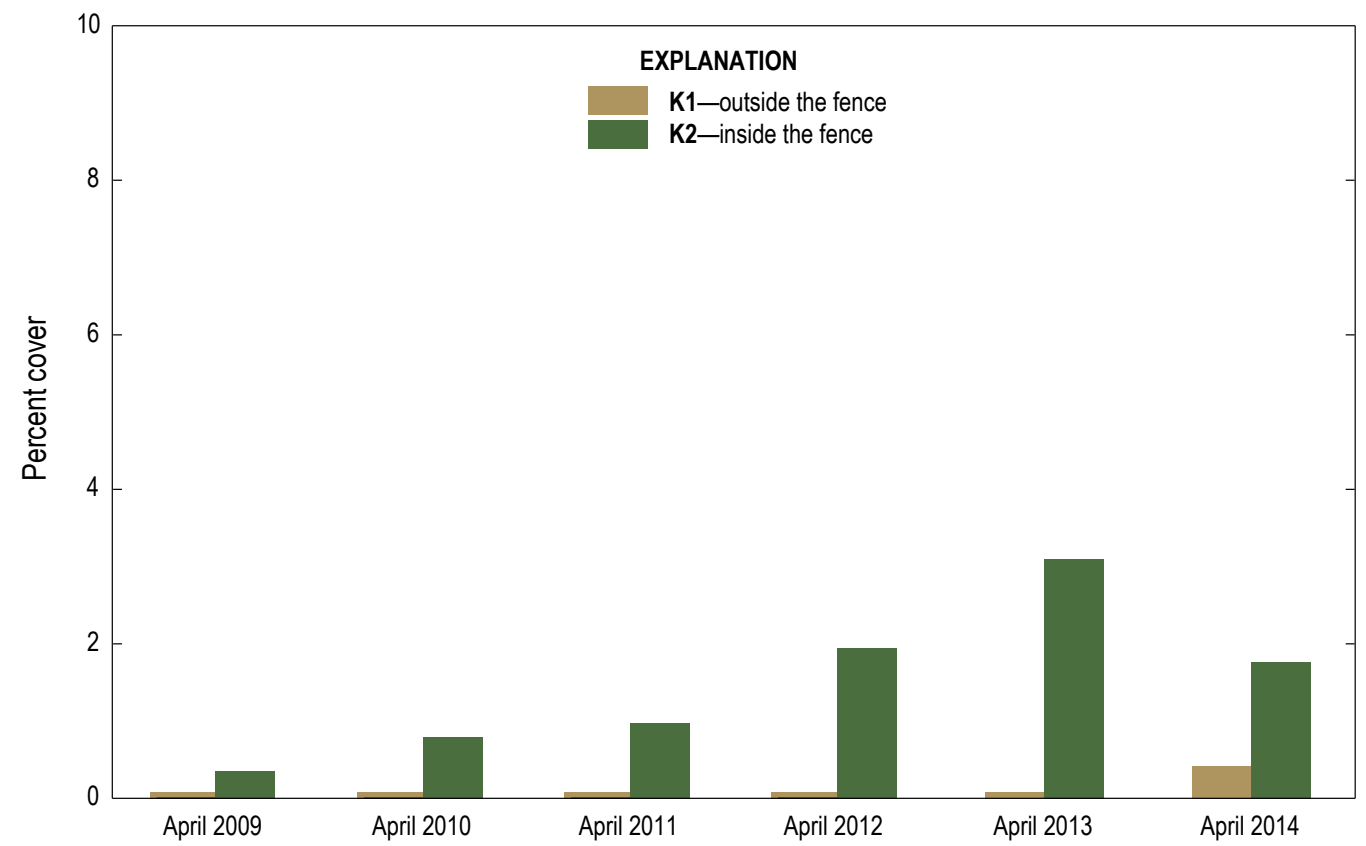

Figure 18. Graph showing percent cover of Tridax procumbens for the April sampling periods within plots K1 and K2 in the U.S. Geological Survey Ridge-to-Reef Moloka'i study area.

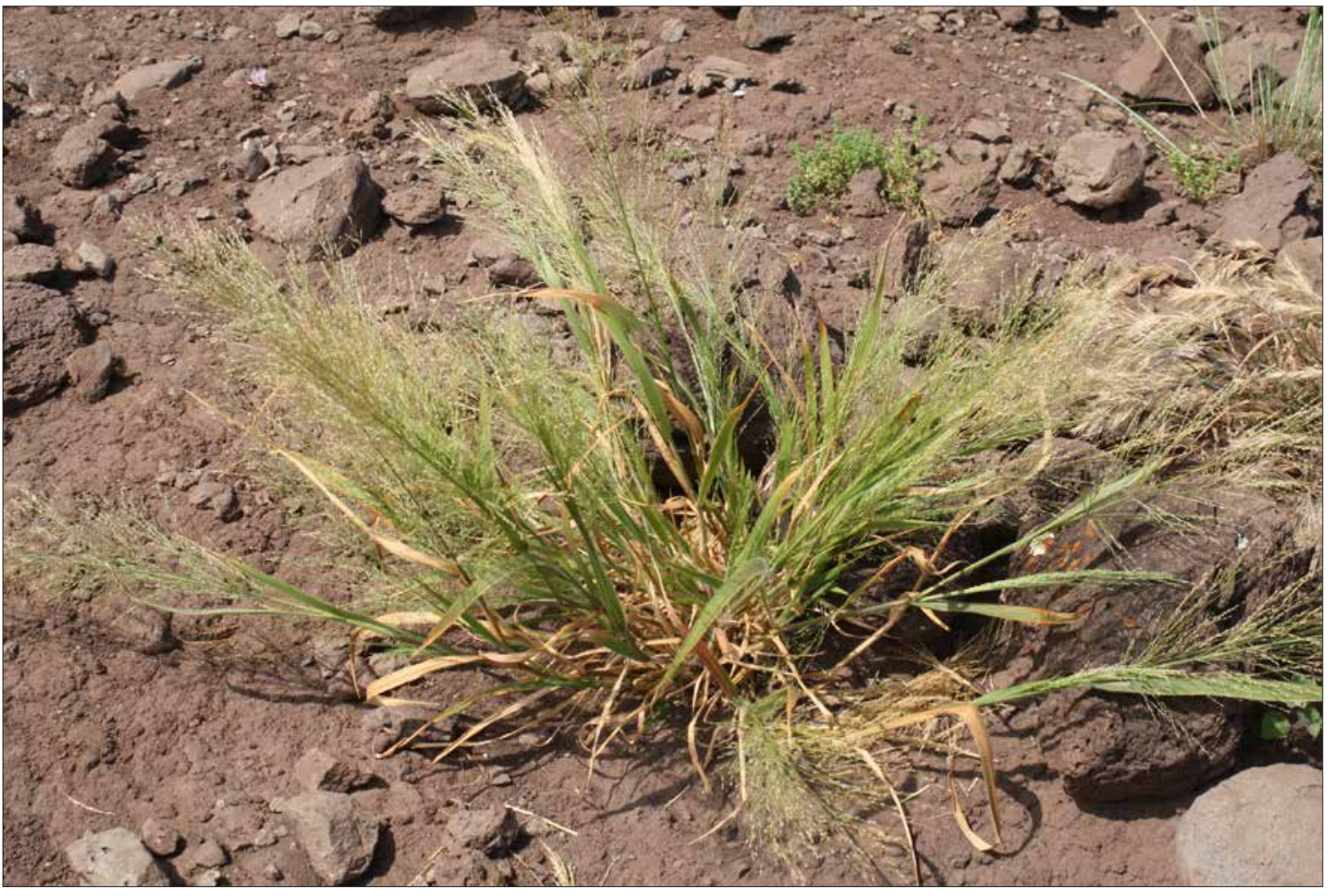

Figure 19. Photograph showing the native annual grass Panicum fauriei var. fauriei growing in plot K2 in the U.S. Geological Survey Ridge-to-Reef Moloka'i study area. 
Figure 20. Photograph showing the native shrub Sida fallax growing in plot $\mathrm{K} 2$ in the U.S. Geological Survey Ridge-to-Reef Moloka'i study area.
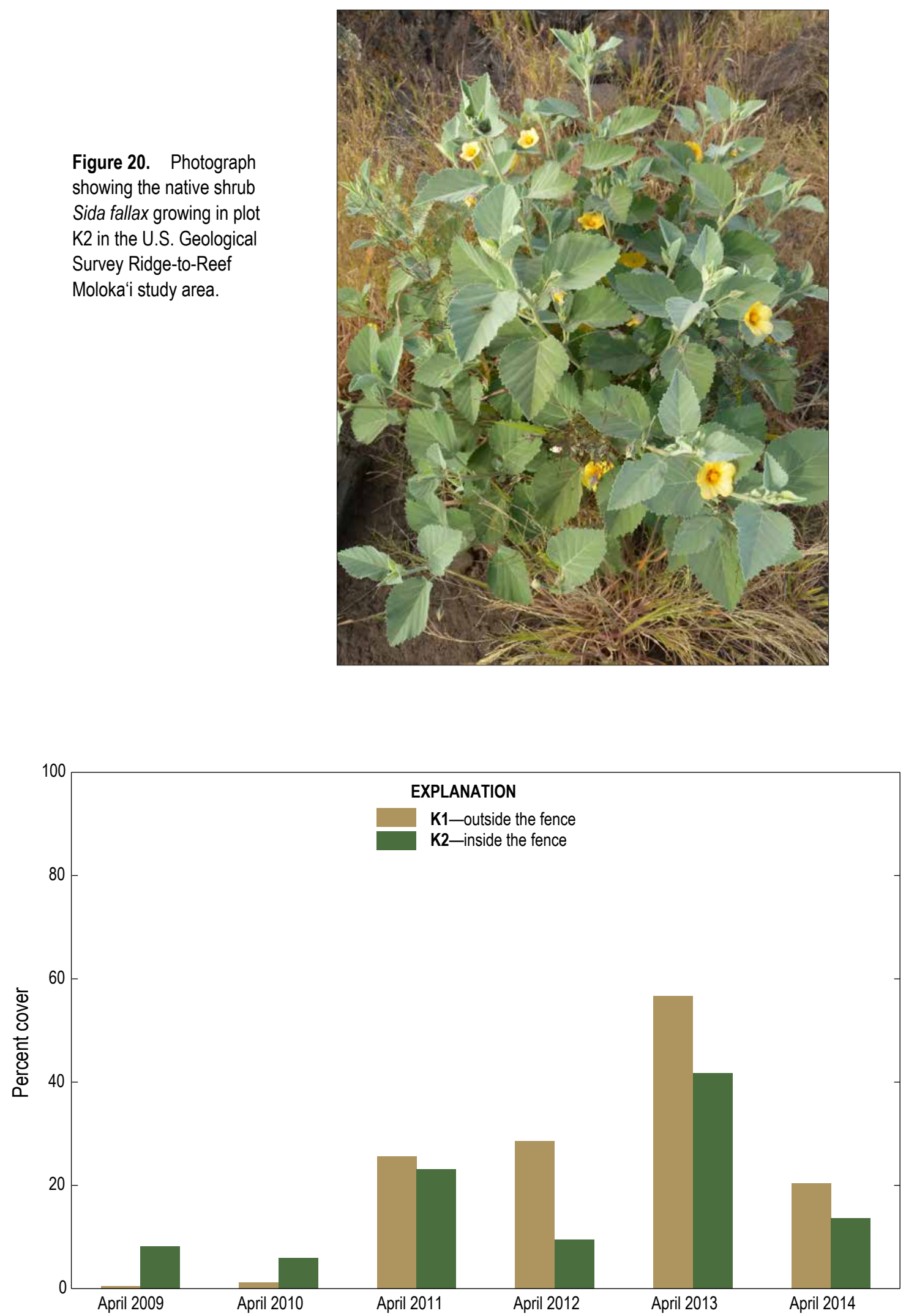

Figure 21. Graph showing percent cover of Panicum fauriei var. fauriei for the April sampling periods within plots K1 and K2 in the U.S. Geological Survey Ridge-to-Reef Moloka'i study area. 


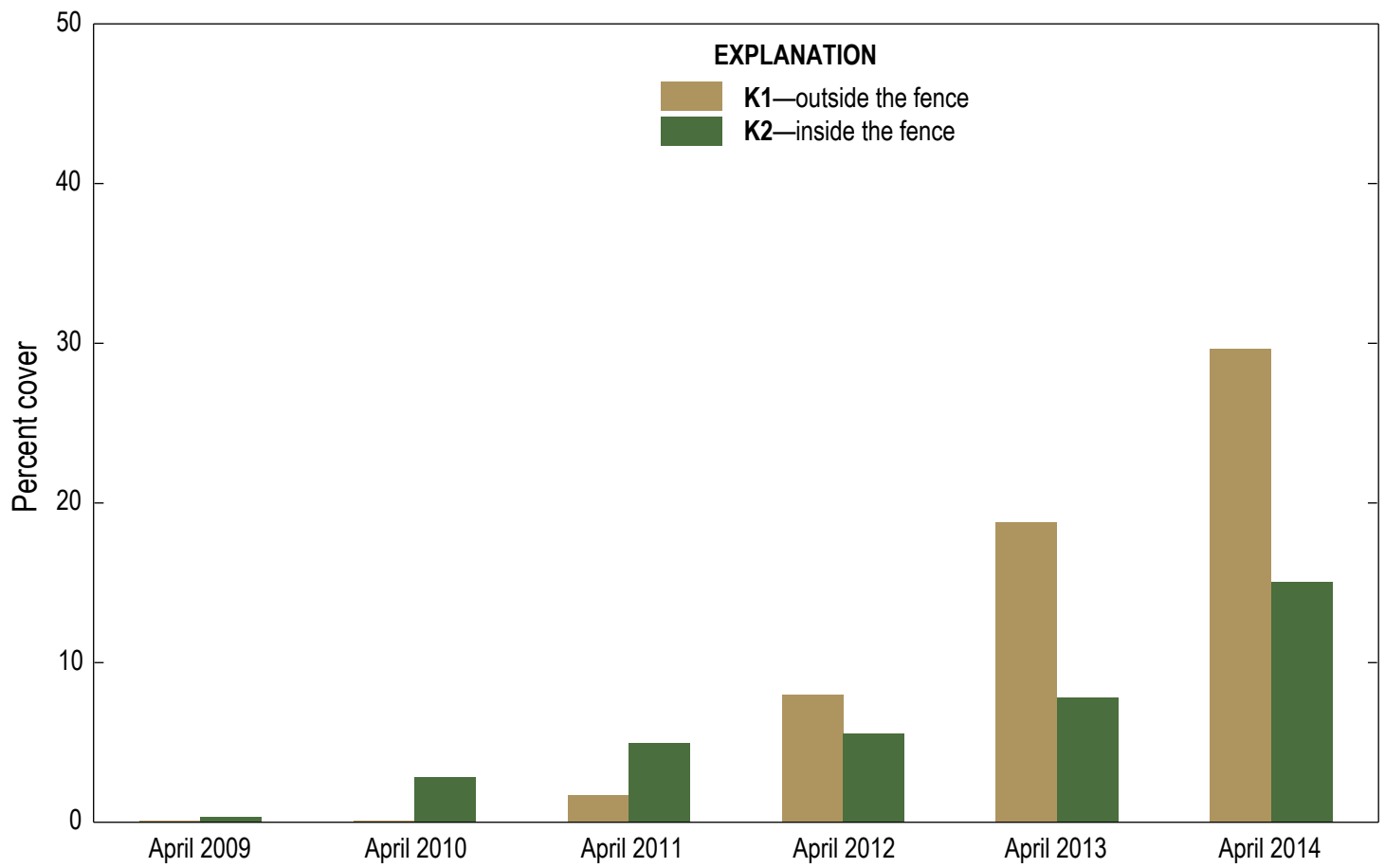

Figure 22. Graph showing percent cover of Sida fallax for the April sampling periods within plots K1 and K2 in the U.S. Geological Survey Ridge-to-Reef Moloka'i study area.

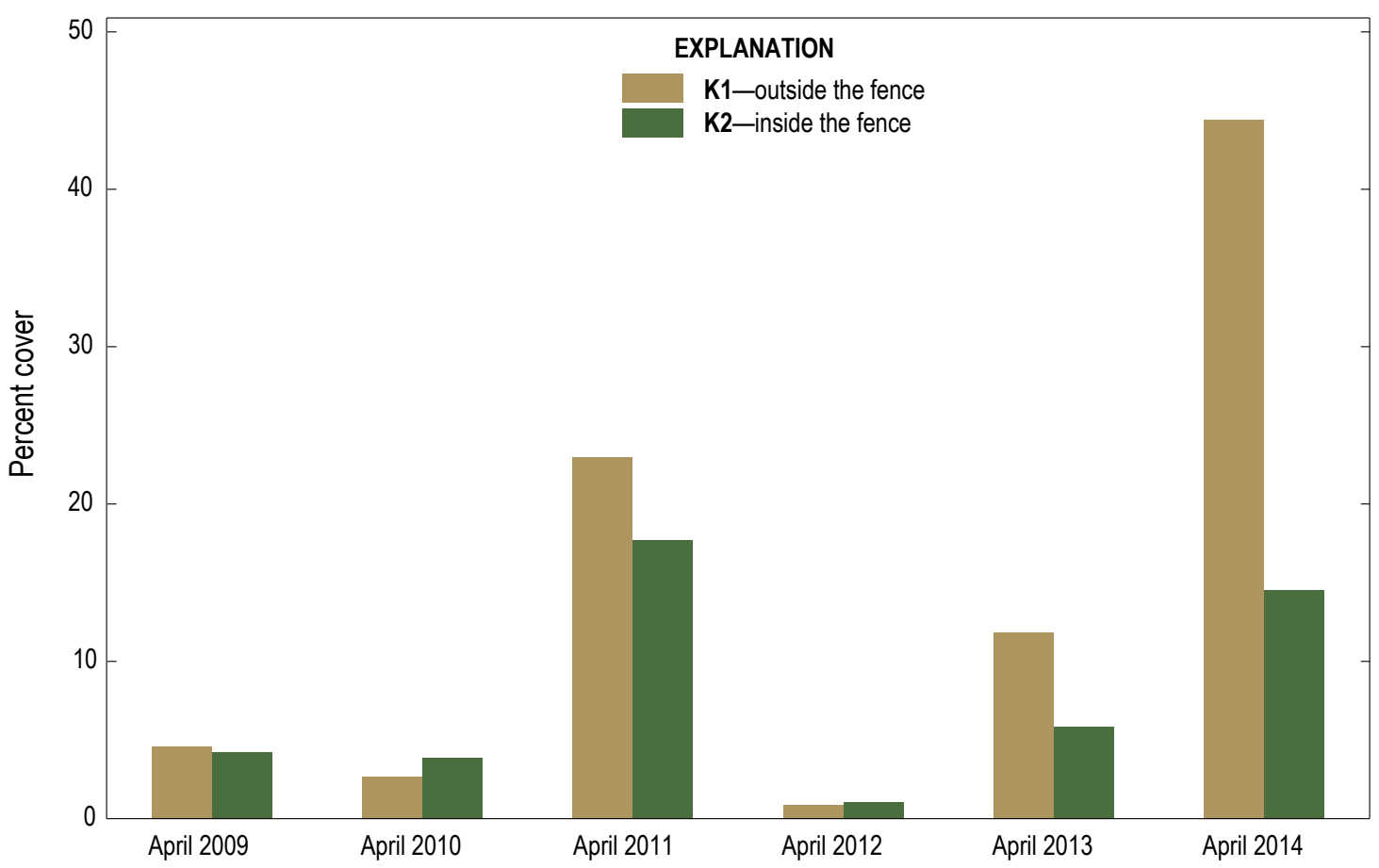

Figure 23. Graph showing percent cover of Festuca myuros for the April sampling periods within plots K1 and K2 in the U.S. Geological Survey Ridge-to-Reef Moloka'i study area. 


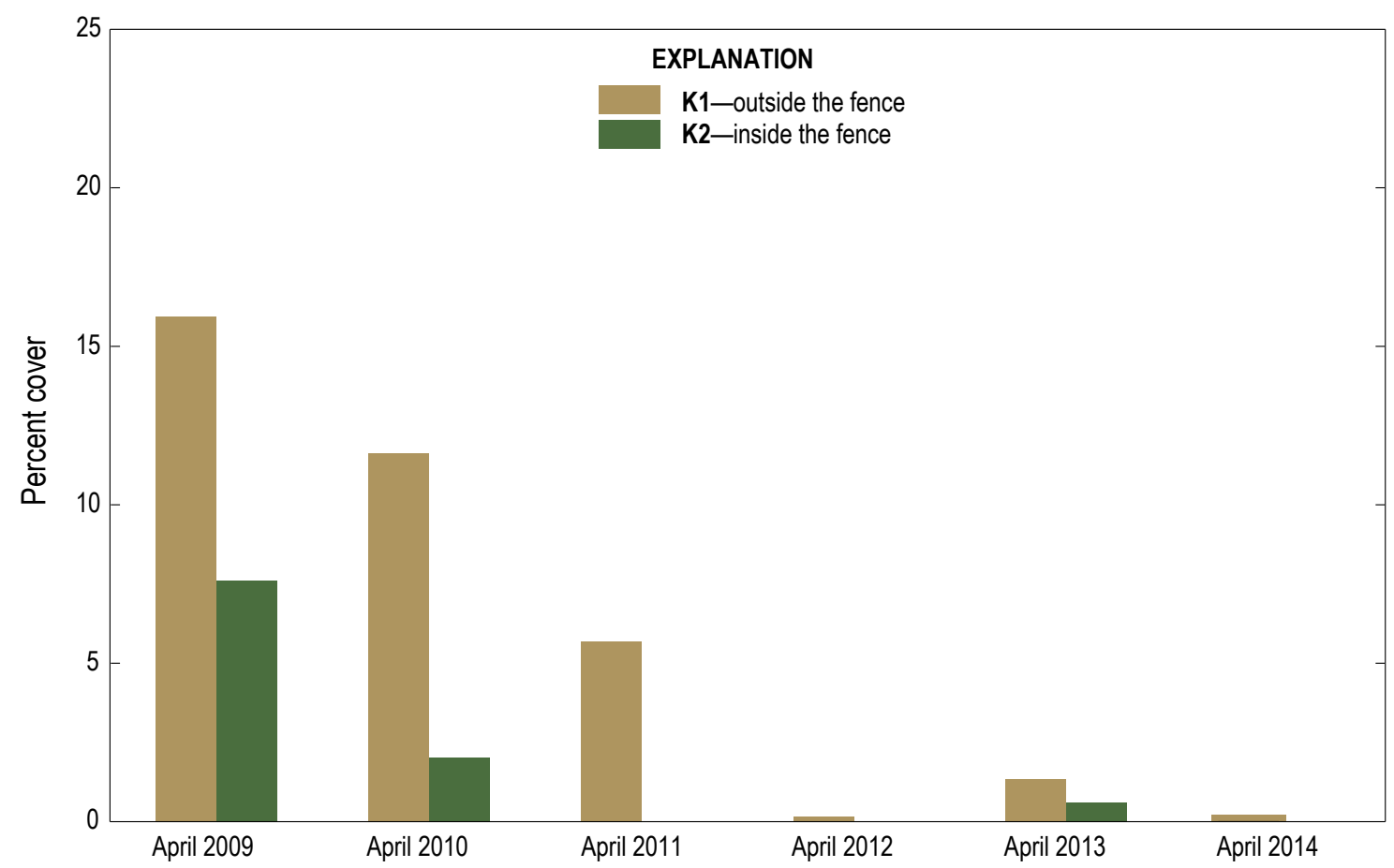

Figure 24. Graph showing percent cover of Dysphania carinata for the April sampling periods within plots K1 and K2 in the U.S. Geological Survey Ridge-to-Reef Moloka'i study area.

in the regression model represents the response of a plant species to animal control overall, and the interaction term represents the fence effect (in other words, inside or outside the fence) on vegetation response to animal control in both sites. Because the interaction term in the model was also significant in all the BLR analyses, we are cautious with interpreting the ecological significance of the main effects term, representing animal control. Although each of the species analyzed with BLR appears to increase in cover over time, the negative sign for the interaction coefficient suggests that the relative increase in cover was less in the fenced plot.

\section{Discussion}

\section{Vegetation Cover Change Relative to Goat Population Levels}

The removal of goats from inside the fenced area and reduction of their numbers outside the fence appears to have led to a significant increase in overall vegetation cover from 2009 to 2014 in both areas (figs. 10, 11, 25, and 26). From April 2009 until April 2010, total vegetation cover remained relatively constant at around 20 percent, both inside and outside the fence. However, during this period there was slightly more plant cover inside the fence at K2 than outside. Starting in April 2011, both areas showed a large increase in total cover for both plots, but with even more vegetation found outside the fence, which still had some goats, than inside the fence without any goat presence (table 5). When viewed from this perspective it appears that the reduction, but not elimination, of goats in this area outside the fence was adequate for regeneration of the vegetation from approximately 20 percent cover in 2009 to more than 60 percent cover in 2014. Two native species, the shrub Sida fallax and the annual grass Panicum fauriei var. fauriei, comprised the bulk of the vegetation recorded in both plots. The increase in above-ground vegetation cover for these species and their associated below-ground roots has potential for reducing erosion of sediment at the site. However, since Panicum fauriei var. fauriei is an annual grass species, it has no live vegetation during the dry season, which reduces its utility for erosion control during these months of the year.

\section{Species Cover Change Relative to Goat Population Levels}

Plant species appear to have had different responses to goat presence and abundance in the two study plots (table 5). For example, Sida fallax was very rare (less than 1 percent) in both the K1 plot and the fenced K2 plot in April 2009. Cover for Sida consistently increased inside the fence until April 2014, when it was recorded at 15 percent. However, a similar but even larger increase was seen for Sida outside the fence in plot K1 starting in April 2011 after the goat population was reduced. Cover for Sida increased from less than 2 percent cover to nearly 30 percent in April 2014 after intensive goat control was initiated across the 


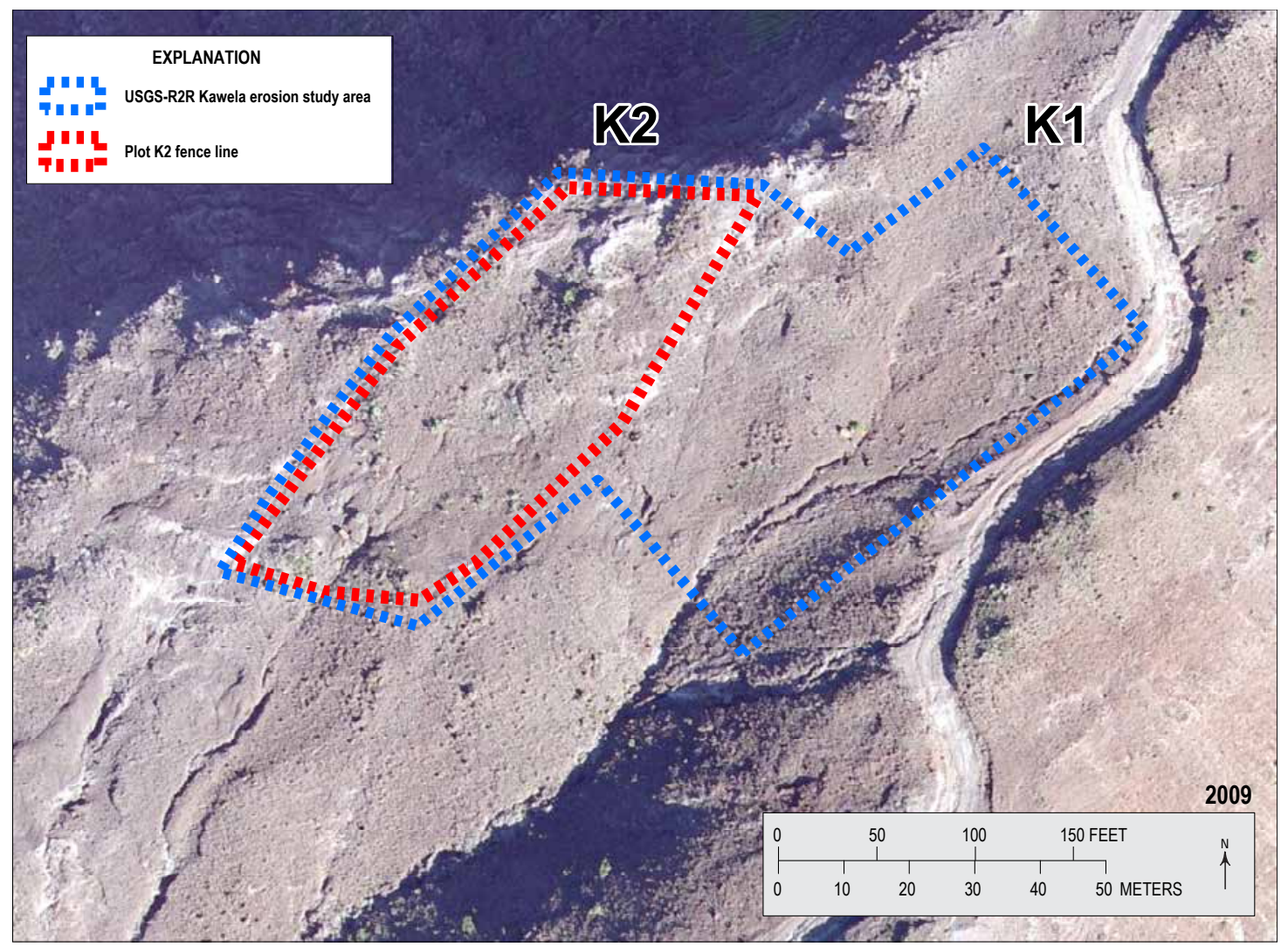

Figure 25. Aerial view of the U.S. Geological Survey Ridge-to-Reef (USGS-R2R) erosion study area in 2009 showing the two plots $\mathrm{K} 1$ and $\mathrm{K} 2$, and the fence line constructed around plot K2. Image copyright by Pictometry International.

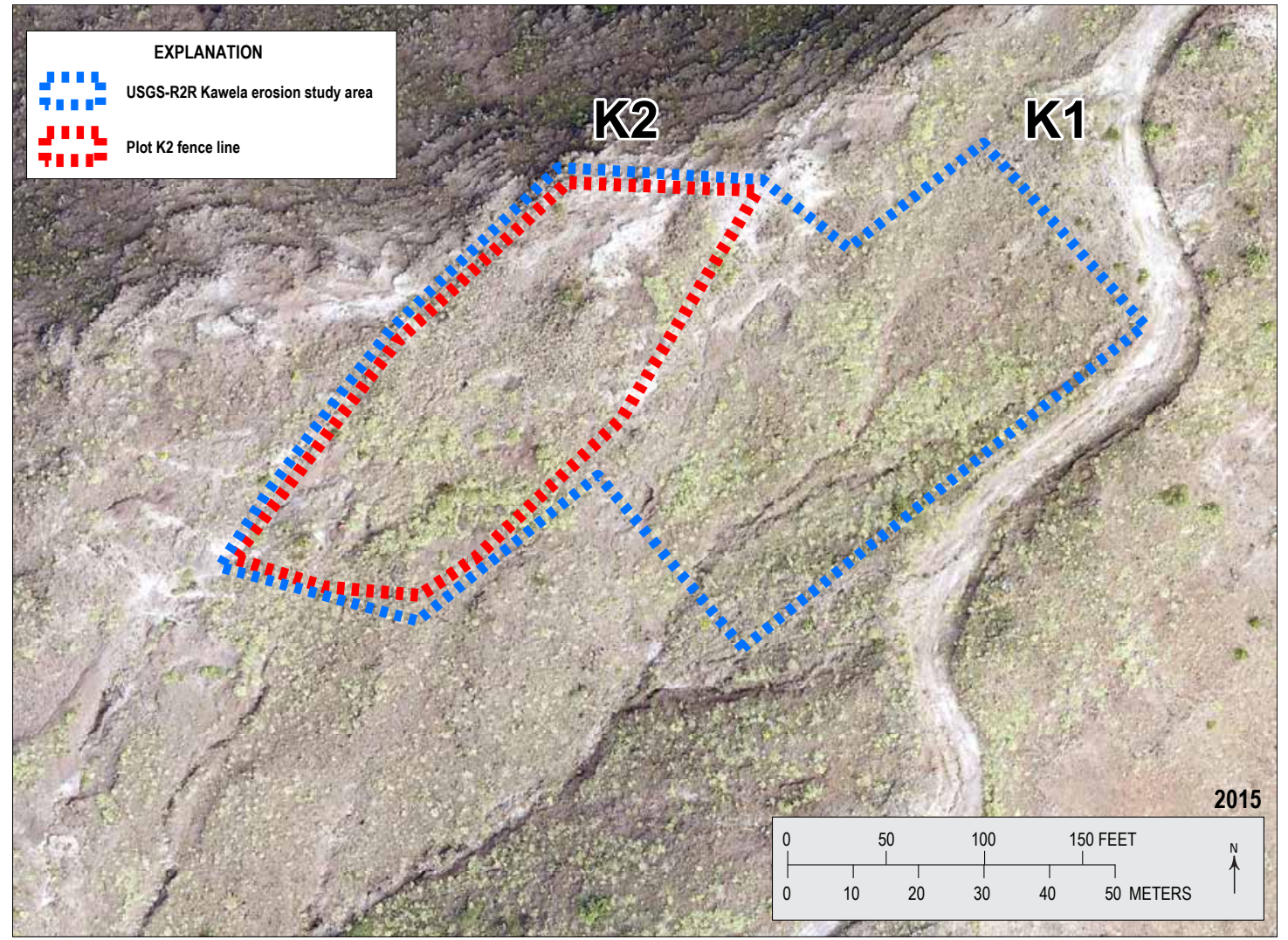

Figure 26. Aerial view of the U.S. Geological Survey Ridge-to-Reef (USGS-R2R) erosion study area in 2015 showing the two plots, $\mathrm{K} 1$ and $\mathrm{K} 2$, and the fence line constructed around plot K2. Image copyright by Pictometry International. 
landscape. The lower cover of Sida inside the fence may be partly a result of the increase in cover of other perennial species that also became established in plot K2, particularly Chenopodium oahuense and Melinis repens. Chenopodium oahuense was totally absent from plot K1 and Melinis repens was only found in K1 with very low cover, likely a result of continued browsing from goats. Panicum fauriei var. fauriei also showed an increase in cover inside the fence after it was constructed in December 2008, and then outside the fence starting in April 2011. Sida was very rare and Panicum was absent in the area when the fence was first established in December 2008, a time that goat populations were essentially uncontrolled and in high abundance across this entire landscape. The fence appears to have provided initial protection for both species, as they increased in cover only in plot K2 in April 2009 and 2010. However, with the initiation of the widespread goat control efforts by the EMoWP starting in 2010, both species appear to have been released from the impacts of goat browsing to the point that they could become established - and show a large increase in cover both inside and outside the fence. Panicum and Sida comprised the clear majority of the vegetation in both plots when they were sampled in April, and their combined abundance explains most of the overall vegetation changes documented during the wet season at these sites between 2009 and 2014. The main difference is that Panicum fauriei var. fauriei is an annual plant and was only found alive during the wetter winter months. The absence or very low cover of both species can be used as an indicator of high levels of goat browsing, as indicated by the differences in recorded cover in 2009-10 inside the fence, where they were completely protected from goats, versus outside the fence, when goats were still abundant.

In contrast, several plant species found in the study area appear to be quite sensitive to even low levels of goat browsing, and may be useful as bioindicators of goat presence in habitats similar to this study area. Chenopodium oahuense was not found established anywhere outside the fence during the study period, even though the goat populations in this region had been greatly reduced from 2010 to 2014. Although a few small C. oahuense seedlings were occasionally seen outside the fence in 2013 and 2014, none of these individuals persisted to the next sampling period, all of them showed signs of heavy browsing by goats, and this species was not recorded at any of the sampling points along the transects in plot K1. The presence of Chenopodium oahuense may be useful as an indicator of the absence, or extremely low population levels, of goats in this habitat. A similar distribution and abundance pattern was shown by the non-native plants Tridax procumbens and Melinis repens, with both species showing an increase in cover inside the fence in K2 from April 2009 until April 2014. However, unlike C. oahuense, these two species were also recorded outside the fence in $\mathrm{K} 1$, but at very low cover in 2013 and 2014. The rest of the plant species recorded within the study plots were rare and with very low cover values, and did not show any discernable patterns in abundance or distribution besides changes owing to seasonal effects.

Although some of the patterns seen with the overall vegetation and selected species cover appear to relate to seasonal rainfall changes as well as changes in goat browsing pressure, the vegetation composition and population dynamics seen in this study represent just the initial stages of secondary succession relative to different levels of human-related impacts at the two plots. As noted previously, the vegetation in the middle and lower portions of the larger USGS-R2R study area has been heavily altered from its original state, particularly resulting from the combined impacts of grazing, browsing, logging, and wildfire. Price and others (2012) identified this mid-elevation area as the upper part of the lowland dry vegetation zone, just adjacent to the lowland mesic zone. The modeled historical ranges for several dominant native tree and shrub species, including lama (Diospyros sandwicensis), 'iliahi (Santalum spp.), hala pepe (Chrysodracon [Pleomele] auwahiensis), 'aweoweo (Chenopodium oahuense), 'a'ali' $\mathrm{i}$ (Dodonaea viscosa), extend into this area; all of these species are still found in small protected remnant sites within the study area (Price and others, 2012). This suggests that the open shrub and grass dominated community currently found on the site is an early successional stage that could eventually develop into a more structured native plant community that includes distinct tree, shrub, and grass/herb components if adverse factors such as ungulates, weeds, and wildfire, were controlled. However, given the degree of damage to this community by grazing and wildfire, and the subsequent invasion of this habitat by several highly invasive non-native species, the ultimate community structure and composition will likely be very different from the native-dominated one that existed here under pre-human conditions.

Although the vegetation found in both study plots is now largely dominated by native species (Sida fallax and Panicum fauriei var. fauriei), there are a number of highly invasive alien plant species in the plots, or in the adjacent area, that could increase in cover and dominate plant community succession here. These include the two Melinis grass species (M. repens and M. minutiflora), as well as the alien shrub Lantana camara, and the tree Grevillia robusta. If the vegetation continues to recover with reduced goat populations in this area, the distribution and abundance of these invasive plant species should be monitored carefully to determine if additional weed control actions are needed.

\section{Linking Vegetation Monitoring to Management}

The loss of the original native vegetation in this study area owing to more than a century of heavy ungulate browsing has likely been one of the major factors leading to excessive local erosion, which affects the downslope coral reef ecosystems. The results of vegetation monitoring at this site between 2009 and 2014 under the different levels of goat browsing - complete elimination from within the fenced area and partial population control outside the fence - can be combined with detailed measurements of rainfall, soil moisture, surface water flow, and sediment transport that have been simultaneously monitored at these two plots. This information, augmented with continued long-term monitoring, can be used to develop a model to estimate the amount of sediment deposition into the downslope coral reef ecosystem under different 
management conditions. This tool would allow land managers to test different management scenarios for this area, including various levels of animal control, revegetation, or wildfire suppression, within a set of realistic environmental conditions that incorporate rainfall seasonality, duration, and variability. Hopefully, this information will provide an objective basis for developing and refining management strategies for upslope habitats, which can reduce the impacts of sediment on the near-shore reef ecosystem.

\section{References Cited}

Allen, R.B., Payten, I.J., and Knowlton, J.E., 1984, Effects of ungulates on structure and species composition in the Urewera forests as shown by exclosures: New Zealand Journal of Ecology, v. 7, p. 119-130.

Brockie, R.E., Loope, L.L., Usher, M.B., and Hamann, O., 1988, Biological invasions of island nature reserves: Biological Conservation, v. 44, no. 1-2, p. 9-36.

Cabin, R.J., Weller, S.G., Lorence, D.H., Flynn, T.W., Sakai, A.K., Sandquist, D., and Hadway, L.J., 2000, Effects of long-term ungulate exclusion and recent alien species control on the preservation and restoration of a Hawaiian tropical dry forest: Conservation Biology, v. 14, no. 2, p. 439-453.

Carlquist, S., 1980, Hawaii-A Natural History (2d ed.): Kauai, Hawaii, Pacific Tropical Botanical Garden, Lawai, 468 p.

Carlson, N.K., 1952, Grazing land problems, Molokai Island, Territory of Hawaii: Journal of Range Management, v. 5, no. 4, p. 230-242.

Chynoweth, M.W., Litton, C.M., Lepczyk, C.A., Hess, S.C., and Cordell, S., 2013, Biology and impacts of Pacific Island invasive species. 9. Capra hircus, the feral goat (Mammalia: Bovidae): Pacific Science, v. 67, no. 2, p. 141-156.

Coblentz, B.E., 1978, The effects of feral goats (Capra hircus) on island ecosystems. Biological Conservation, v. 13, no. 4, p. $279-286$.

Cole, R., and Litton, C., 2014, Vegetation response to removal of non-native feral pigs from Hawaiian tropical montane wet forest: Biological Invasions, v. 16, no. 1, p. 125-140.

Cooke, G.P., 1949, Moolelo o Molokai, a ranch story of Molokai: Honolulu, HI, Honolulu Star-Bulletin, 164 p.

Cuddihy, L.W., and Stone, C.P., 1990, Alteration of native Hawaiian vegetation - Effects of humans, their activities and introductions: Honolulu, HI, Cooperative National Park Resources Studies Unit University of Hawai i, 138 p.

Elzinga, C.L., Salzer, D.W., Willoughby, J.W., and Gibbs, J., 2001, Monitoring plant and animal populations: Denver, Colo., Blackwell Science Ltd., 360 p.
Field, M.E., Cochran, S.A., Logan, J.B., and Storlazzi, C.D., eds., 2008, The coral reef of south Molokai, Hawai' $i$; portrait of a sediment-threatened fringing reef: U.S. Geological Survey Scientific Investigations Report 20075101, 180 p.

Giambelluca, T.W., Chen, Q., Frazier, A.G., Price, J.P., Chen, Y.-L., Chu, P.-S., Eischeid, J.K., and Delparte, D.M., 2012, Online rainfall atlas of Hawai' $i$ : Bulletin of the American Meteorological Society, v. 94, no. 3, p. 313-316.

Hawai'i Association of Watershed Partnerships, 2014, East Moloka'i Watershed Partnership: Hawaii Department of Land and Natural Resources, Division of Forestry and Wildlife web page, accessed June 2016, at http://hawp.org/ partnerships/east-molokai-watershed/.

Hess, S.C., Banko, P.C., Brenner, G.J., and Jacobi, J.D., 1999, Factors related to the recovery of subalpine woodland on Mauna Kea, Hawaii: Biotropica, v. 31, no. 2, p. 212-219.

Hughes, G., Cohan, A., White, M., and Brown, E., 2014, Subalpine vegetation change 14 years after feral animal removal on windward east Maui, Hawai'i: Pacific Science, v. 68 , no. 1 , p. $19-31$.

Jacobi, J.D., 1981, Vegetation changes in a subalpine grassland in Hawaii following disturbance by feral pigs: Cooperative National Park Resources Studies Unit, University of Hawaii, Department of Botany, Honolulu, Technical Report $41,25 \mathrm{p}$.

Jacobi, J.D., and Ambagis, S.M., 2013, Vegetation map of the watersheds between Kawela and Kamalō Gulches, Island of Moloka'i, Hawai'i: U.S. Geological Survey Scientific Investigations Report 2013-5093.

Juvik, S.P., Juvik, J.O., and Paradise T.R., 1998, Atlas of Hawaii ( $3 \mathrm{~d}$ ed.): Honolulu, HI, University of Hawai'i Press, $333 \mathrm{p}$.

Kawela Plantation Homeowners' Association, [2014], Kawela Plantation Homeowners' Association: Kawela Plantation Homeowners' Association web page, accessed June 2016 at http://www.kawelapha.com/.

Kirch, P.V., 2007, Three islands and an archipelagoReciprocal interactions between humans and island ecosystems in Polynesia: Earth and Environmental Science Transactions of the Royal Society of Edinburgh, v. 98, no. 1, p. 85-99.

Kirch, P.V., 2011, When did the Polynesians settle Hawaii? A review of 150 years of scholarly inquiry and a tentative answer: Hawaiian Archaeology, v. 12, p. 2-26.

Kirch, P.V., and Hunt, T.L., 1997. Historical ecology in the Pacific Islands: Environmental and landscape change New Haven, Conn., Yale University Press, 352 p. 
Leopold, C.R. and Hess, S.C., 2017, Conversion of native terrestrial ecosystems in Hawai' $i$ to novel grazing systems-A review: Biological Invasions, v. 19, no. 1, p. 161-177.

Loope, L.L., Sanchez, P.G., Tarr, P.W., Loope, W.L., and Anderson, R.L., 1988, Biological invasions of arid land nature reserves: Biological Conservation, v. 44, no. 1-2, p. $95-118$.

Loope, L.L., and Scowcroft, P.G., 1985, Vegetation response within exclosures in Hawaii, in Stone, C.P., and Scott, J.M., edis., Hawaii's terrestrial ecosystems - Preservation and management: Cooperative National Park Resources Studies Unit, University of Hawai ${ }^{i}$, Department of Botany, Honolulu, p. 377-402.

Maly, K., and Wilcox, B.A., 2000, A short history of cattle and range management in Hawai'i: Rangelands, v. 22, no. 5, p. 21-23.

Mueller-Dombois, D., and Ellenberg, H., 2002, Aims and methods of vegetation ecology ( $2 \mathrm{~d}$ ed.): Caldwell, New Jersey, The Blackburn Press, $547 \mathrm{p}$.

Pratt, L.W., and Jacobi, J.D., 2009, Loss, degradation, and persistence of habitats, in Pratt, T.K., Atkinson, C.T., Banko, P.C., Jacobi, J.D., and Woodworth, B.L., eds., Conservation biology of Hawaiian forest birds, implications for island avifauna: New Haven, Conn., Yale University Press, p. $139-158$.

Price, J.P., Jacobi, J.D., Gon, III, S.M., Matsuwaki, D., Mehrhoff, L., Wagner, W.L., Lucas, M., and Rowe, B., 2012, Mapping plant species ranges in the Hawaiian IslandsDeveloping a methodology and associated GIS layers: U.S. Geological Survey Open-File Report 2012-1192, 38 p.

Scowcroft, P.G., and Giffin. J., 1983, Feral herbivores suppress mamane and other browse species on Mauna Kea, Hawaii: Journal of Range Management, v. 36, no. 5, p. 638-645.

Sherrod, D.R., Sinton, J.M., Watkins, S.E., and Brunt, K.M., 2007, Geologic map of the State of Hawai'i: U.S. Geological Survey Open-File Report 2007-1089, scale 1:100,000 and 1:250,000.
Smith, C.W., 1985, Impact of alien plants on Hawaii's native biota, in Stone, C.P., and Scott, J.M., eds., Hawaii's terrestrial ecosystems - Preservation and management: Cooperative National Park Resources Studies Unit, University of Hawai' i, Department of Botany, Honolulu, HI, p. 180-250.

Staples, G.W., and Cowie, R.H., eds., 2001, Hawaii's invasive species-A guide to invasive plants and animals in the Hawaiian Islands (1st ed.): Honolulu, HI, Mutual Publishing and the Bishop Museum Press, 111 p.

Stock, J.D., Cochran, S.A., Field, M.E., Jacobi, J.D., and Tribble. G., 2011, From ridge to reef-Linking erosion and changing watersheds to impacts on the coral reef ecosystems of Hawai' $i$ and the Pacific Ocean: U.S. Geological Survey Fact Sheet 2011-3049, 4 p.

Stone, C.P. and Scott, J.M., eds., 1985, Hawaii's terrestrial ecosystems - Preservation and Management, Proceedings of a symposium June 5-6, 1984, Hawaii Volcanoes National Park: Cooperative National Park Resources Studies Unit, University of Hawai 'i, Department of Botany, Honolulu, HI, 584 p.

Tomich, P.Q., 1986, Mammals in Hawaii (2d ed.): Honolulu, HI, Bishop Museum, 375 p.

U.S. Department of Agriculture, Gridded soil survey geographic (gSSURGO) database for Hawaii: Natural Resources Conservation Service, accessed January 2016, at https:// www.nrcs.usda.gov/wps/portal/nrcs/detail/soils/survey/ geo/?cid=nrcs142p2_053628.

U.S. Geological Survey, 2014, National elevation dataset: U.S. Geological Survey National Map database, accessed June 2016, at http://nationalmap.gov/elevation.html.

Wagner, W.L., and Funk, V.A., eds., 1995, Hawaiian biogeography-Evolution on a hot spot archipeligo: Washington D.C., Smithsonian Institution Press, 467 p.

Warshauer, F.R., 1998, Alien species and threats to native ecology, in Juvik, S.P., Juvik, J.O., and Paradise, T.R., eds., Atlas of Hawaii: Honolulu, HI, University of Hawai'i Press, p. 146-149.

Ziegler, A.C., 2002, Hawaiian natural history, ecology and evolution: Honolulu, HI, University of Hawai'i Press, 477 p. 
Appendix 


\section{Appendix-Species List}

List of all plant species found in, or adjacent to, plots K1 or K2 during all the sampling periods. Species recorded at least once during the vegetation transect surveys are marked with "Yes". The taxonomy follows Wagner and others (2005).

[E, endemic; I, indigenous; X, alien]

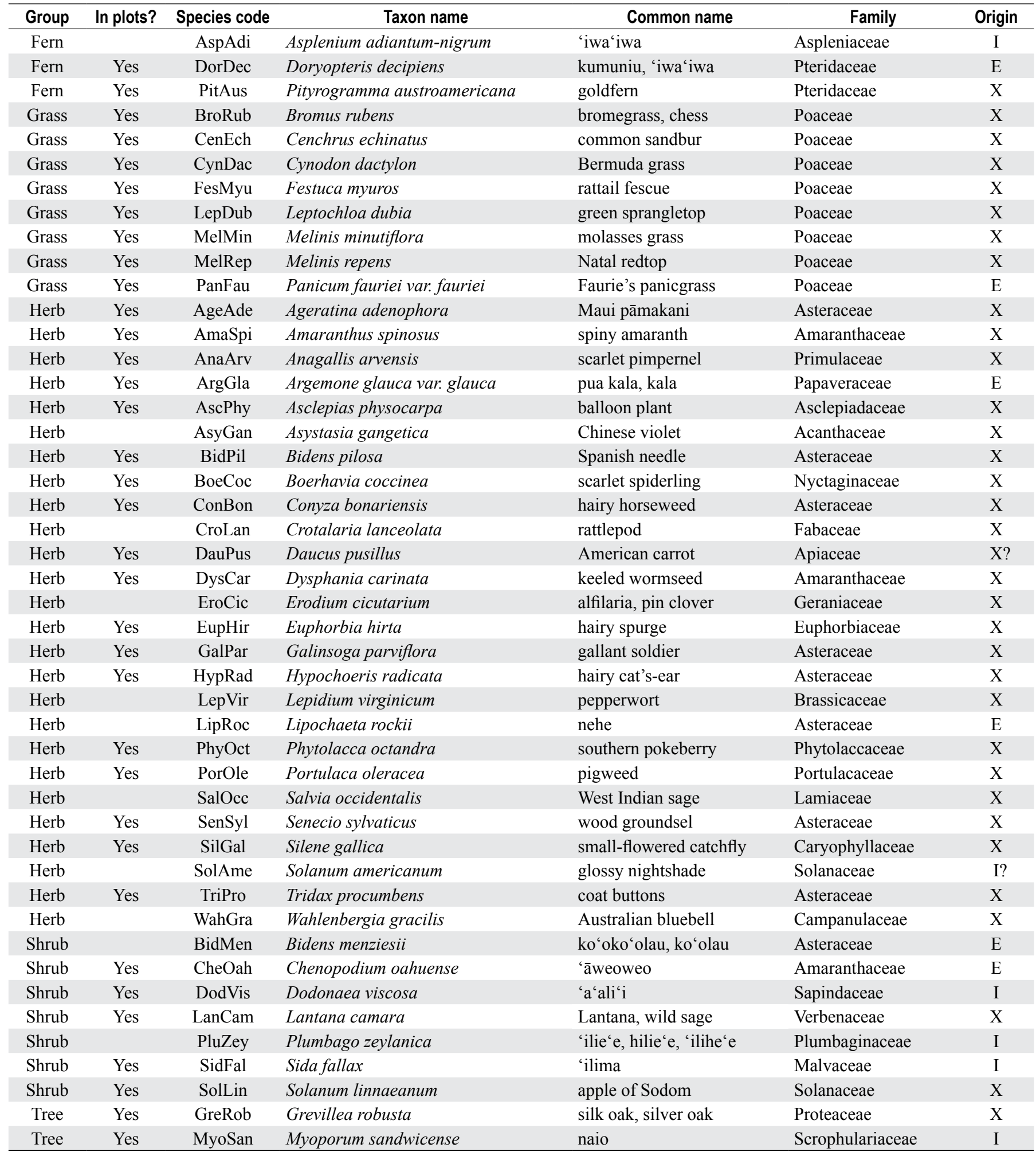


Menlo Park Publishing Service Center, California

Manuscript approved for publication November 7, 2017

Edited by Katherine D. Jacques

Layout and design by Cory D. Hurd 


\section{$\frac{2}{2}$}

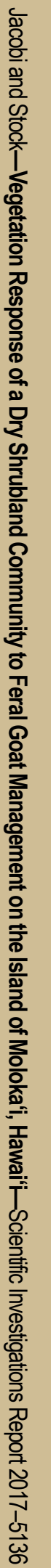

